\title{
THE FESTUCO-BROMETEA GRASSLANDS ON SANDSTONE AND MARL-CLAY-SANDSTONE SUBSTRATA IN TUSCANY (NORTHERN-CENTRAL ITALY)
}

\author{
Bruno FOGGI ${ }^{1}$, Lorenzo LASTRUCGI ${ }^{1}$, Matilde GENNAI ${ }^{1}$ \& \\ Daniele VICIANI ${ }^{1}$
}

\begin{abstract}
The grasslands dominated by Bromus erectus and/or Brachypodium rupestre cover large areas on sandstone and marl-clay-sandstone substrata (limestone is excluded), of the Apennines and pre-Apennines between Pistoia and Arezzo provinces (Tuscany, Central Italy). Our investigation was focused on to 71 unpublished relevés and 45 literature relevés from Tuscany and surrounding areas, reporting the original relevés of Astragalo monspessulani-Brometum erecti, Centaureo bracteatae-Brometum erecti and Ononido masquillerii-Brometum erecti. The relevés were submitted to exploratory multivariate analysis, allowing to detect nine distinct groups. Their consistence was verified by mean of NMDS against Ellenberg/Pignatti indicator values, and CCA constrained against chorotypes and growth forms. Diagnostic species of the definitive groups resulting from the analysis were chosen according to species fidelity, based on the $\varphi$ coefficient of association. The analysis splits the data set in two main subclusters; the first one (A) includes few relevés of low altitude, thermophilous conenoses, interpreted as a transition between the submediterranean aspects of Festuco-Brometea class and other Mediterranean herbaceous and shrubby classes; the second subcluster (B) includes most of the data set and can be clearly subdivided in pioneering, mesoxerophilous communities (B1 and B2a groups) and mesophilous communities (B2b group). The relevés of clusters B1 and B2a are referred to Coronillo minimae-Astragaletum monspessulanii association and to three other groups: Plantago argentea-Carex caryophyllea communities, Tragopogon samaritani-Bromus erectus communities, Festuco trachyphyllae-Brometum erecti ass. nova. The mesophilous group (B2b) includes the original Centaureo bracteatae-Brometum erecti and Ononido masquillerii-Brometum erecti relevés, together with a slightly differentiated community; due to the non-relevant differences between these grassland types from floristic, ecological and chorological perspectives, we propose herewith to treat them as three subassociations of Centaureo bracteatae-Brometum erecti (typicum, ononidetosum masquillerii and linetosum cathartici). Post-cultural grasslands in human-disturbed areas were also detected. All these communities can be attributed to Polygalo mediterraneae-Bromenion erecti suballiance (Bromion alliance), even if a clear subdivision between the mesoxerophilous pioneer aspects and the more mesophilous and evolved ones can be noted.
\end{abstract}

Keywords: Bromion erecti, Ellenberg Indicator Values, grasslands, multivariate analysis, Northern Apennines, phytosociology, syntaxonomy.

\section{Izvleček}

Travišča v katerih prevladujeta vrsti Bromus erectus in/ali Brachypodium rupestre pokrivajo velike površine na podlagi iz peščenjaka in laporasto-glinastega peščenjaka (apnenec je izključen) na Apeninih in območju pred njimi med provincama Pistoia in Arezzo (Toskana, srednja Italija). Naša raziskava je bila osredotočena na 71 neobjavljenih in 45 objavljenih vegetacijskih popisov iz Toskane in sosednjih območij. Originalni popisi opisujejo asociacije Astragalo monspessulani-Brometum erecti, Centaureo bracteatae-Brometum erecti in Ononido masquillerii-Brometum erecti. Popise smo obdelali z multivariatno analizo s katero smo zaznali 9 skupin. Konsistenstnost skupin smo preverili s povprečjem NMDS proti Ellenberg/Pignatti indikatorskim vrednostim

\footnotetext{
${ }^{1}$ Department of Biology, Laboratory of Botany, University of Florence, Via La Pira 4, I-50121 Florence, Italy. E-mail: bruno.foggi@unifi.it (corresponding author), lastruccilorenzo73@gmail.com, matizgen@gmail.com, daniele.viciani@unif.it
} 
in CCA proti horotipom in rastnim oblikam. Diagnostične vrste posameznih skupin smo določili z navezanostjo vrst, ki temelji na $\varphi$ koeficientu asociacije. $\mathrm{Z}$ analizo smo podatkovni niz razdelili na dva klastra; prvi (A) vključuje nekaj popisov termofilne cenoze $\mathrm{z}$ nižje nadmorske višine, ki jih opišemo kot prehod med submediteranskim aspektom razreda Festuco-Brometea in drugih mediteranskih zeliščnih in grmiščnih razredov; drugi klaster (B) pa vključuje večino podatkovnega niza in ga lahko členimo na pionirske, mezokserofilne (skupini B1 in B2a) in mezofilne združbe (skupina B2b). Popise klastrov B1 in B2a uvrščamo v asociacijo Coronillo minimae-Astragaletum monspessulanii in tri druge skupine: združba Plantago argentea-Carex caryophyllea, združba Tragopogon samaritani-Bromus erectus in Festuco trachyphyllae-Brometum erecti ass. nova. Mezofilna skupina (B2b) vključuje popise asociacij Centaureo bracteatae-Brometum erecti in Ononido masquillerii-Brometum erecti, skupaj z delno spremenjeno združbo. Zaradi majhnih razlik v florističnem, ekološkem in horološkem pogledu med temi traviščnimi tipi predlagamo, da jih obravnavamo kot tri subasociacije Centaureo bracteatae-Brometum erecti (typicum, ononidetosum masquillerii in linetosum cathartici). Opisali smo tudi nekaj negospodarjenih travišč na motenih rastiščih. Vse združbe lahko uvrstimo v podzvezo Polygalo mediterraneae-Bromenion erecti (podzveza Bromion), čeprav je opazna delitev med mezokserofilnim pionirskim in mezofilnim in bolj razvitim aspektom.

Ključne besede: Bromion erecti, Ellenbergove indikatorske vrednosti, travišča, multivariatna analiza, severni Apenini, fitosociologija, sintaksonomija.

\section{INTRODUCTION}

European dry grasslands belonging to FestucoBrometea class are considered by the European Community as seminatural habitats of high conservation value, listed in Annex I of the Habitat Directive (92/43 EEC, with Natura2000 codes 6210, 62A0): their presence and conservation are generally related to human management (Biondi 2005). In the last two decades several papers were devoted to the syntaxonomical problems of these communities in Europe (see Royer 1991; Mucina \& Kolbek 1993, Dengler et al. 2003, 2006, Dengler 2004, Chytrý et al. 2007, Mucina et al. 2009, Terzi 2011), including Italy, with particular concern on the peninsular regions (Biondi et al. 1995, 2005, Di Pietro 2011, Biondi \& Galdenzi 2012). Based on the afore mentioned literature data about Italy, some considerations raised: i) much of the information on this vegetation type consists in local contributions mainly focused on the limestone substrata of central and southern Apennines; ii) very few studies have been carried out in the north-western Apennines (e.g. Castelli 1995, Zanotti et al. 1995, 1998, Castelli et al. 2001, Barcella \& Assini 2013).

In past and recent revisions of Apennine Festuco-Brometea grasslands, whose references are quoted above, contributions from Tuscany were poorly represented. Indeed published vegetation relevés attributed to this class in the Tuscan region are usually dispersed in extensive vegetation surveys of restricted areas and invariably analyzed apart without comparing all the avail- able data and without the aim to define general floristic-ecological trends. Moreover, most of the available data refer to dry grasslands on calcareous and ultramafic substrata (Arrigoni et al. 1983, 1997, Arrigoni \& Bartolini 1997, Casini \& De Dominicis 1999, Viciani et al. 2002a, Arrigoni 2003, Angiolini et al. 2003, 2009, Lastrucci et al. 2009, Viciani \& Gabellini 2013, etc.), whereas information about sandstone and marl-claysandstone substrata is scarce, and addressed to restricted areas in eastern Tuscany (Biondi et al. 1985, 1988, De Dominicis et al. 2002, Viciani et al. 2002b, 2004, Viciani \& Gabellini 2006). In two of the above quoted papers, two new associations were described: Coronillo minimae-Astragaletum monspessulani (Biondi et al. 1985) and Ononido masquillerii-Brometum erecti (Biondi et al. 1988). Recently, several field research promoted by Local Administrations were carried out, mainly in order to improve the knowledge on habitats of conservation concern (e.g. Foggi \& Venturi 2009), allowing to collect several new dry grassland vegetation relevés.

In order to implement the phytosociological knowledge on the Festuco-Brometea grasslands growing on non-calcareous substrata, we focus on the following questions:

1) is the diversity of Tuscan vegetation types on sandstone and marl-clay-sandstone substrata already known?

2) is the traditional classification of the FestucoBrometea class at the level of orders, alliances and suballiances adequate to describe these vegetation types? 


\section{MATERIAL AND METHODS}

\subsection{Data sources and vegetation SAMPLING}

A total of 71 original phytosociological relevés were performed with Braun-Blanquet $(1932,1964)$ method also in accordance to the pragmatic rules given by Dengler et al. $(2005,2008)$. The general position of all the relevés used for the analysis has been reported on Figure 1. These relevés are deposited in an Access data-base of the Laboratory of Botany the Department of Biology, University of Florence and are at disposition under request. All data exclusively concern grasslands located on sandstone or marl-clay-sandstone substrata, according to the geological map by Carmignani \& Lazzarotto (2004). Original relevés have been performed in 2007-2010 spring and summer periods, in a strictly homogeneity of physiognomy and physiography according to Géhu (1988). We only sampled grasslands where the dominance of grass species (Poaceae) and other herbs was clear and where only a little visible effect of succession was observed. The 45 published relevés included the original tables of some associations, described in Tuscany or in the surrounding areas and/or reported in vegetation studies for Tuscan areas. The references of the published relevés we used and a list of the original relevés with their geographical coordinates are reported in Appendix 1. Some literature relevés were excluded because of their high shrub cover values (no relevé with more than $25 \%$ shrub cover value was considered).

Vascular plant nomenclature was unified following Conti et al. $(2005,2007)$ with very few exceptions due to more recent nomenclatural changes.

The attribution to syntaxonomic ranks higher than association level and the selection of diagnostic species were determined by comparison with specific literature (Oberdorfer 1978, Biondi et al. 1995, 2005, Rivas-Martínez et al. 2002, Dengler et al. 2003, Chytrý 2007, Mucina et al. 2009, Biondi \& Galdenzi 2012), besides some other sources quoted specifically in the text.

The syntaxonomic nomenclature follows the International Code of Phytosociological Nomenclature (Weber et al. 2000).

\subsection{Vegetation classification}

All 116 relevés (Table 1) were submitted to classification (cluster analysis) and ordination (PCoA and NMDS) with statistical software (package Syntax V, Podani 2002; PAST, Hammer et al.
Figure 1: Map of the study area and sites of the relevés. Abbreviations: AT - Artimino; SP - Alta Svizzera Pesciatina; VS - Vallesanta; AL - Alpe della Luna; SC - Scalette; DG - Monte Dogana; GZ - Monte Ginezzo; PO - Alpe di Poti; MV Monteverde; MN - Monte Nero; SS - Sasso di Simone; AC - Alpe di Catenaia; FC - National Park of Casentino Forests.

Slika 1: Zemljevid proučevanega območja in lokacije popisov. Okrajšave: AT - Artimino; SP Alta Svizzera Pesciatina; VS - Vallesanta; AL - Alpe della Luna; SC - Scalette; DG - Monte Dogana; GZ - Monte Ginezzo; PO - Alpe di Poti; MV - Monteverde; MN Monte Nero; SS - Sasso di Simone; AC - Alpe di Catenaia; FC - Nacionalni park Casentino.

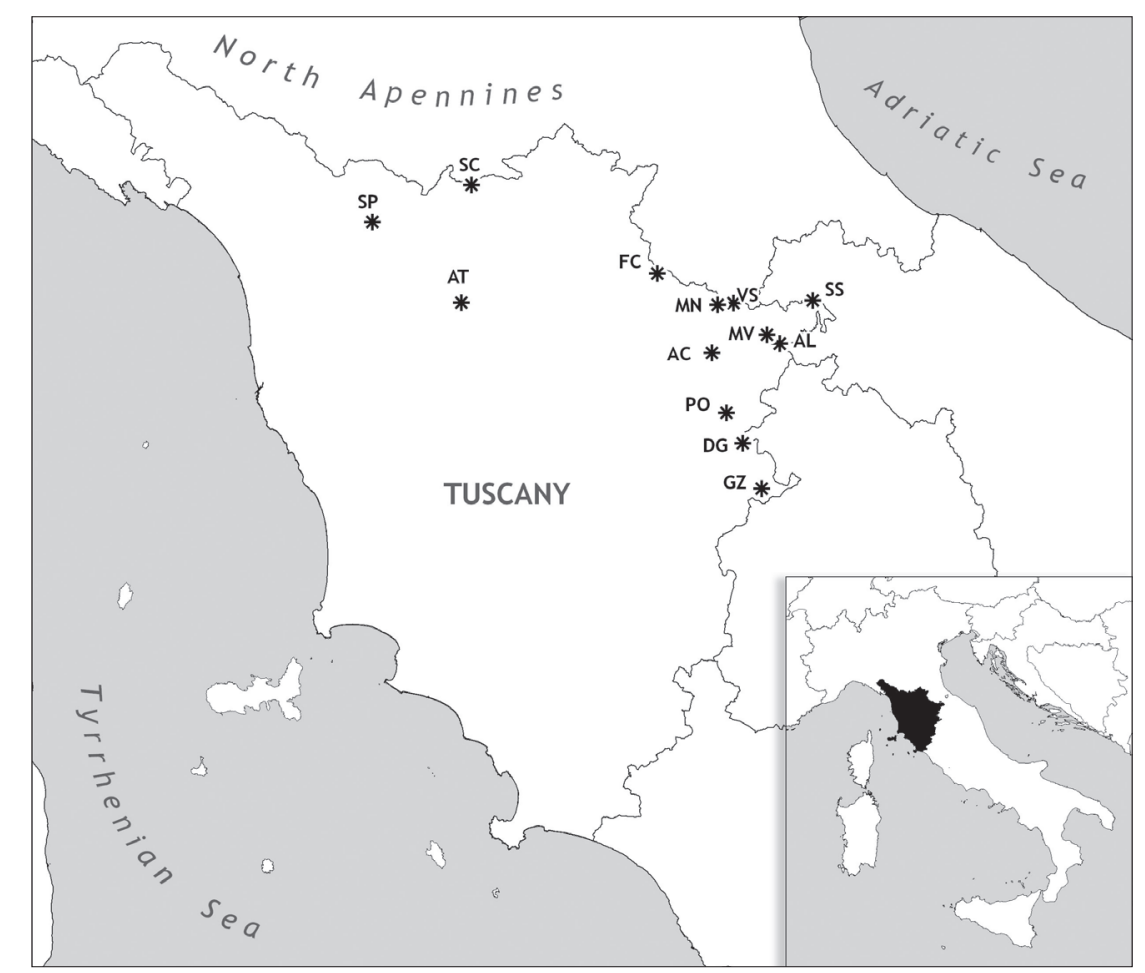


2001). For cluster analysis we used UPGMA algorithm with Bray-Curtis as distance measure; for NMDS we used a Bray-Curtis distance too. Diagnostic species of the main vegetation units, obtained by the numerical classification, were identified using the phi-coefficient of association (Chytrý et al. 2002), performed by software JUICE 7 (Tichý 2002). According to Chytrý (2007), species with phi $\geq 0.50$ were considered as highly diagnostic, and species with phi $>0.25$ as diagnostic. The species whose concentration according to Fisher's exact test was not significant at $\mathrm{p}<0.01$ were disregarded. Furthermore, for the already described syntaxa, we reported the species considered as characteristic/differential by the authors of that syntaxon only if they proved to have a relevant phi-coefficient in our relevés. The relevés in Table 1 are arranged according to these procedures. Finally, some relevés were re-arranged according to our personal knowledge of the species and of the ecological situation of the sites.

We calculated un-weighted Ellenberg/Pignatti Ecological Indicator Value mean (EIV) for temperature, nutrients, moisture, soil reaction and continentality (Ellenberg et al. 2001, Pignatti 2005) and chorotypes (Arrigoni 1983, Takhtajan 1986). Furthermore we calculated weighted principal growth forms (Arrigoni 1996).

In addition, constrained ordinations of the hypothesized groups were performed through canonical correspondence analysis (CCA) according to the distribution of species and growth forms. Its effect on the ordination pattern was tested using the Monte Carlo test with 9999 random permutations. The ecological requirements (indirectly calculated by mean of EIV) were plotted against the unconstrained NMDS ordination of the relevés.

\section{RESULTS}

The cluster analysis performed on the data set of 116 relevés (Figure 2) shows two principal subclusters (A and B). The subcluster A encompasses a small group of relevés made at low altitudes in the central part of the study area. They are floristically well-distinguished for a relevant cover of Mediterranean suffrutices and scrubs (Dorycnium hirsutum, Cistus monspeliensis, Teucrium capitatum) that are found in the class Rosmarinetea (RivasMartinez et al. 1991) and for the presence of thermophilous herbaceous species like Bothriochloa ischaemum, Melica ciliata, Galactites tomentosa, etc.

The second subcluster (B) can be further divided in two main groups: the smaller one (B1) includes relevés from the Pistoia province characterized by mesoxerophilous species as Plantago argentea and Koeleria lobata; the second larger group (B2) is further divided in two principal subgroups. B2a encompasses Coronillo minimae-Astragaletum monspessulani original relevés (B2a1) and other pioneer floristically differentiated communities related to scarcely evolved soils confined on mountain areas of northern-central (B2a2) and eastern Tuscany (B2a3).

The B2b subcluster can be referred to grasslands on more evolved and mesophilous soils and encompasses several distinguishable subgroups: mesophilous communities located in eastern Apennines (B2b1), Centaureo bracteatae-Brometum erecti original relevés and some other Tuscan relevés (B2b2), Ononido masquillerii-Brometum erecti association present only on Sasso di Simone and Simoncello Mt. (B2b3), finally a group of similar conenoses more strongly characterized by ruderal and human managed meadow species (B2b4).

The groups distinguished by cluster analysis have been tested against the Ellenberg/Pignatti Ecological Indicator values (EIV), the chorotypes and the growth forms (Figures 3, 4,5). The EIV NMDS (Figure 3) shows that groups B2b1, B2b2 and B2b3 appears positively related to nutrient $(\mathrm{N})$, water availability (U) and soil reaction (R); others (B1 and B2a3) to temperature (T) and light (L) and negatively related to moisture (U). B2a1 and B2a2 groups appears to be more oligotrophic, while A results clearly separated from all the others groups and seems to be strictly related to T. Group A is well distinguished also in the chorological CCA (Figure 4), because of its floristic composition very rich in Mediterranean species. B1 and $\mathrm{B} 2 \mathrm{a} 3$ have a relevant portion of Mediterranean and Euro-Mediterranean elements, while the more mesophilous groups resulted to be characterized by European and Eurasiatic chorotypes. Some discriminating features can be illustrated also by the growth form CCA (Figure 5), as some groups are positively related to the presence of graminoid and non-graminoid annual herbs (B1 and B2a3), others to a relevant portion of suffrutices (B2a1, B2a2), others to nongraminoid perennial herbs (B2b1, B2b2, B2b3).

In the synoptic table (Table 2 ) the fidelity phicoefficient (Chytrý et al. 2002, Tichý 2002) of the diagnostic species was also reported. 


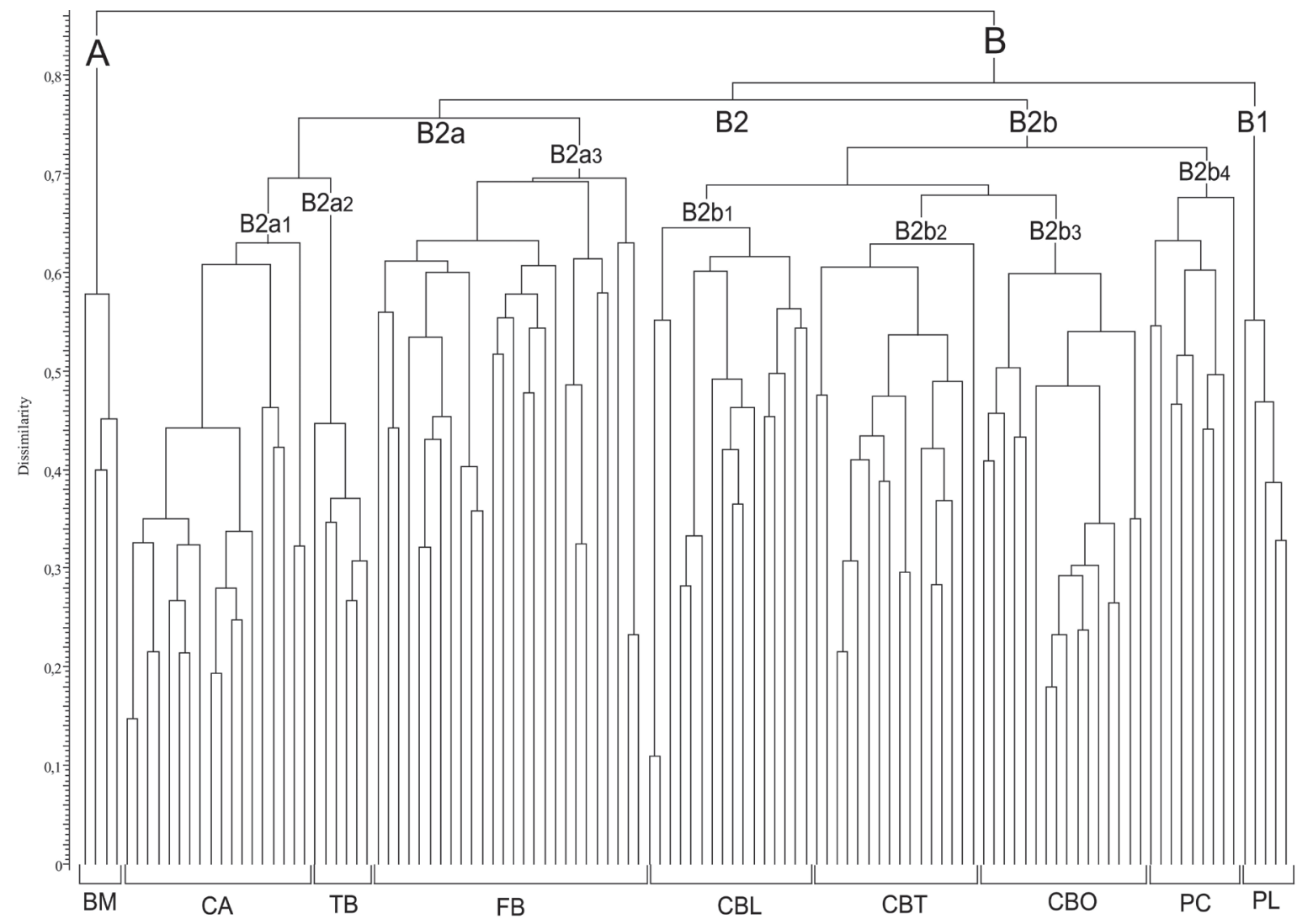

Figure 2: Dendrogram of phytosociological relevés. Group A - Bothriochloa ischaemum-Melica ciliata comm.(BM); group B1 - Plantago argentea-Carex caryophyllea comm. (PL); group B2a1 - Coronillo minimae-Astragaletum monspessulani (CA); group B2a2 - Tragopogon samaritani-Bromus erectus comm. (TB); group B2a3 - Festuco trachyphyllae-Brometum erecti (FB); group B2b1 - Centaureo bracteatae-Brometum erecti linetosum cathartici (CBL); group B2b2 - Centaureo bracteatae-Brometum erecti typicum (CBT); group B2b3 - Centaureo bracteatae-Brometum erecti ononidetosum masquillierii (CBO); group B2b4 - Cichorium intybus-Bromus erectus post-cultural comm. (PC).

Slika 2: Dendrogram fitocenoloških popisov. Skupina A - združba Bothriochloa ischaemum-Melica ciliata(BM); skupina B1 - združba Plantago argentea-Carex caryophyllea (PL); skupina B2a1 - Coronillo minimae-Astragaletum monspessulani (CA); skupina B2a2 - združba Tragopogon samaritani-Bromus erectus (TB); group B2a3 - Festuco trachyphyllae-Brometum erecti (FB); skupina B2b1 - Centaureo bracteatae-Brometum erecti linetosum cathartici (CBL); skupina B2b2 - Centaureo bracteatae-Brometum erecti typicum (CBT); skupina B2b3 - Centaureo bracteatae-Brometum erecti ononidetosum masquillierii (CBO); skupina B2b4 - združba Cichorium intybus-Bromus erectus (PC).

\section{DISCUSSION}

\subsection{Group A - Bothriochloa ISCHAEMUM- MELICA CILIATA COMMUNITIES (TABLE 1, REL. 1-4)}

Diagnostic species: Brachypodium rupestre, Bromus erectus, Bothriochloa ischaemum, Melica ciliata, Avena barbata, Centaurea deusta, Galactites tomentosus, Onobrys caput-galli.

These communities are termophilous grasslands located at very low-altitudes (70-145 m a.s.l.) near Montalbano hills (Prato Province) on clay-sandstone substrata. Several grass species (above mentioned) are co-dominant and many herbs (Galactites tomentosa, Crupina vulgaris) and suffrutices belonging to Mediterranean vegetation are present (Teucrium capitatum, Micromeria graeca, Dorycnium hirsutum, etc.). The strong dominance of Mediterranean elements is evidenced by CCA of the chorotypes (Figure 4); the EIV NMDS (Figure 3) highlights the termophilous and xerophilous character of these conenoses. Presence of some species as Bothriochloa ischaemum, Micromeria graeca, Teucrium capitatum, etc., once attributed to Xerobromion and recently 


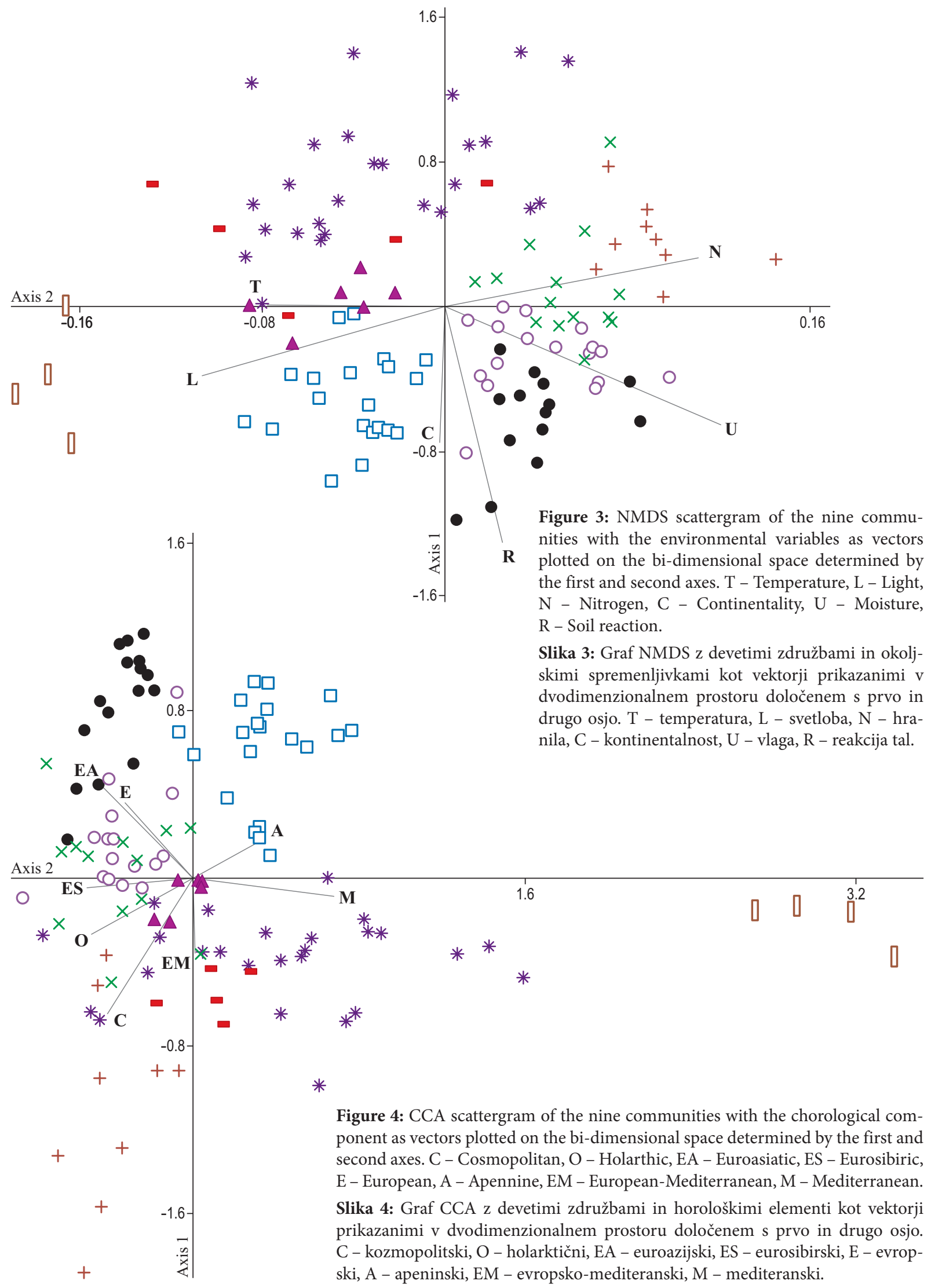




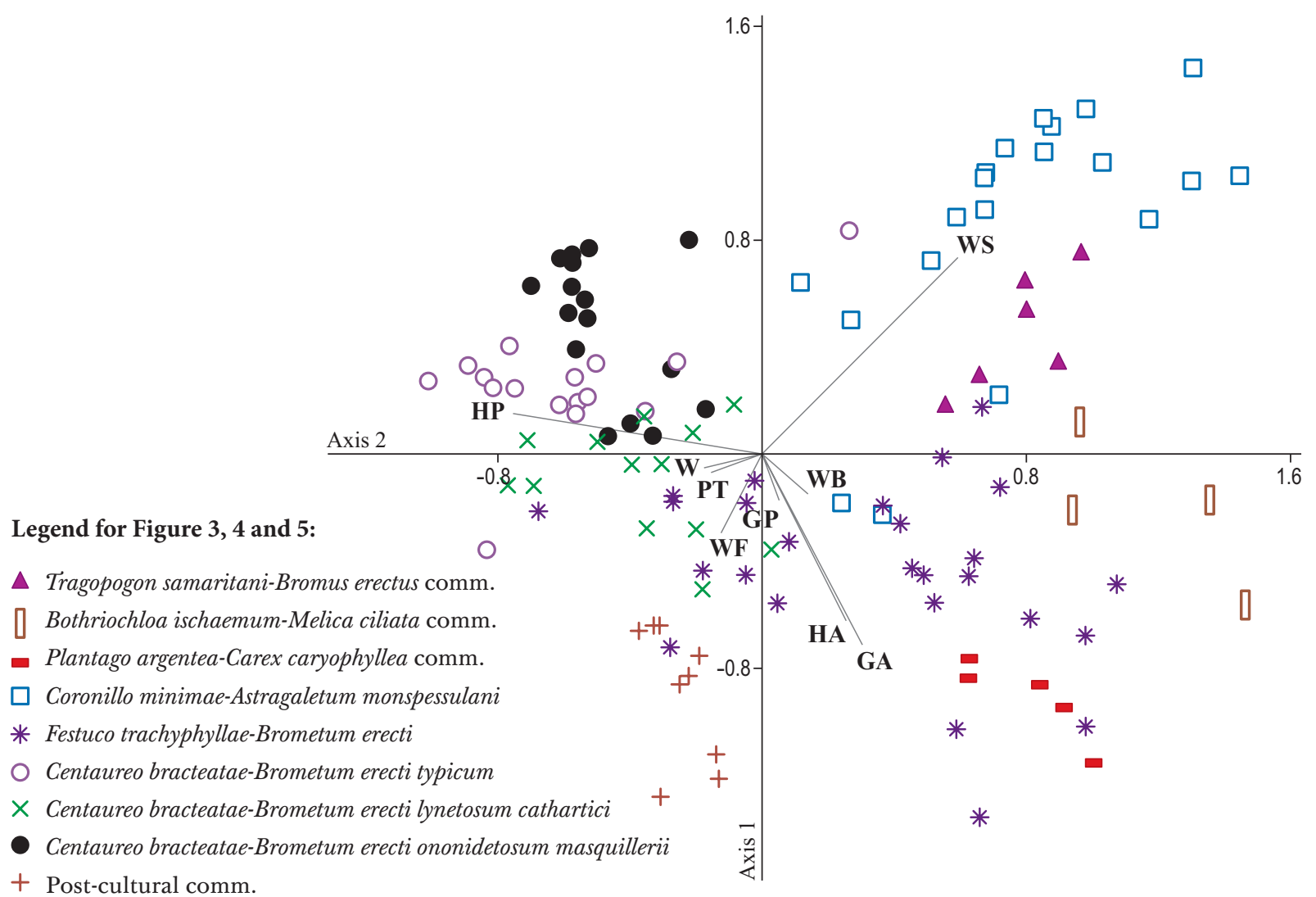

Figure 5: CCA scattergram of the nine communities with the growth forms as vectors plotted on the bi-dimensional space determined by the first and second axes. W - Trees, WB - Scrubs, WS - Suffrutex, WF - Frutex and Lianes, HP - Perennial Herbs, HA - Annual Herbs, GP - Perennial Grasses, GA - Annual Grasses, PT - Pteridophytes.

Slika 5: Graf CCA z devetimi združbami in rastnimi oblikami kot vektorji prikazanimi v dvodimenzionalnem prostoru določenem s prvo in drugo osjo. W - drevesa, WB - grmi, WS - pritlični grmi, WF - grmi in ovijalke, HP - trajna zelišča, HA - enoletna zelišča, GP - trajne trave, GA - enoletne trave, PT - praproti.

re-attributed to Rosmarinetea (Biondi et al. 2005), as well as the ecological features, suggest to interpret these communities as a transition between the submediterranean aspects of Festuco-Brometea class and other Mediterranean herbaceous and shrubby classes, particularly Rosmarinetea officinalis. For these reasons they are not included in the final syntaxonomical scheme.

\subsection{Group B1 - Plantago argentea- CAREX CARYOPHYLLEA GOMMUNITIES (TABLE 1, REL. 5-9)}

Diagnostic species: Plantago argentea, Koeleria lobata, Aira caryophyllea, Centaurea arrigonii, Poa bulbosa, Hypochaeris radicata, Cerastium pumilum, Medicago minima, Bromus rubens.
This vegetation type has been recorded exclusively in Pistoia Apennines at altitudes around $1000 \mathrm{~m}$ a.s.l., on marly-clay-sandstone substrata. As shown by the NMDS of EIV (Figure 3), heliophilous, oligotrophic and xerophilous species are found to be dominant of these open pioneer grasslands growing on thin soils. The community is dominated by Bromus erectus and Carex caryophyllea, with other species belonging to more mesoxerophilous syntaxa of the Festuco-Brometea (Plantago argentea, Koeleria lobata, Centaurea arrigonii, etc.) and differentiated by annual pioneer graminoid and non-graminoid species (Aira caryophyllea, Poa bulbosa, Cerastium pumilum, Medicago minima, etc.) as shown by the growth form CCA (GA and HA in Figure 5). The relevant portion of Euro-Mediterranean chorotypes (Figure 4) confirms the slightly thermophilous character of 
the community. From a syndynamic perspective, these grasslands tend to be invaded by funiperus communis stands; the mature forest stage is not clear and is probably linked to mesophilous-subacidophilous Quercus cerris woods (Gennai 2011).

\subsection{Group B2A1 - Coronillo MiNimae- ASTRAGALETUM MONSPESSULANI BIONDI \& Ballelli in Biondi, Ballelli \& Principi 1985 (TABle 1, Rel. 10-30)}

Diagnostic species: Coronilla minima, Astragalus monspessulanus, Linum tenuifolium, Leontodon rosani, Fumana procumbens. (In the original description of the association Centaurea jacea subsp. gaudinii was considered a characteristic species, but afterwards it was included in the differential species of Polygalo mediterraneae-Bromenion erecti suballiance by Biondi et al. 2005; Fumana procumbens was added as diagnostic species by Biondi et al. 2005)

This syntaxon was firstly described for eastern Tuscan Apennines (Alpe della Luna, Badia Tedalda) and some other localities at the boundaries with Marche, Umbria and Emilia-Romagna regions (Biondi et al., 1985). The field survey extends the presence of this association also in the Casentino Valley (Valle Santa). The association refers to pioneer vegetation with Astragalus monspessulanus, Coronilla minima, Centaurea ambigua, Fumana procumbens, Linum tenuifolim etc.; it grows on scarcely evolved soils, subjected to a certain degree of erosion, on arenaceous or, more often, marl-clay-sandstone substrata. The association was originally assigned to Xerobromion alliance due the high presence of xerophilous species (Biondi et al. 1985, 1986) but in the most recent revision of Apennine grasslands belonging to Brometalia erecti order (Biondi et al. 2005) the association was attributed to the Bromion erecti alliance, representing its pioneer aspect. The EIV NMDS (Figure 3) evidences the xeroheliophilous and oligotrophic character of these communities and the growth form CCA (Figure 5) shows a relevant presence of suffrutices (WS). The community appears to be chorologically characterized by Apennine elements (Figure 4). With the soil evolution, the association tends to evolve towards more mesophilous and nitrophilous grasslands such as Centaureo bracteatae-Brometum erecti (Biondi et al., 1986, Viciani et al. 2002b). From a syndynamical perspective, in Tuscan sites the mature forest vegetation consists mainly of mixed subacidophilous Quercus cerris wood (Cephalanthero longifoliae-Querco cerridis sigmetum and Melico uniflorae-Querco cerridis sigmetum, see De Dominicis et al. 2010). In some localities of the study area (Alpe della Luna: rel. 25 and 26) an impoverished aspect of the subassociation seslerietosum italicae Zanotti, Ubaldi \& Puppi 1995 was found (Viciani et al. 2002b). The subassociation, described for the Emilia-Romagna sector of the Apennines (Zanotti et al. 1995) in lower aridity conditions with respect to the typical association (see Biondi et al. 1985), is differentiated by species such as Sesleria italica, Campanula medium, Festuca robustifolia (maybe confused with other Festuca species) and Euphorbia cyparissias.

\subsection{Group B2a 2 - Tragopogon SAMARITANI-BROMUS ERECTUS COMMUNities (TABLE 1, REL. 31-36)}

Diagnostic species: Tragopogon samaritani, Teucrium montanum, Arenaria serpyllifolia, Crepis staticifolia, Silene vulgaris, Thymus pulegioides.

This vegetation type can be found on oligotrophic soils derived from sandstone substrata, in the northern-central part of the study area (Prato Apennines), at altitudes around $1100 \mathrm{~m}$ a.s.l. It consists in open, meso-subacidophilous grasslands dominated by Festuca inops, Bromus erectus, etc. The soil is shallow and not well developed, rich in debris, as clearly evidenced by the presence of some specialized species (Anthyllis vulneraria, Sedum sexangulare, Astragalus monspessulanus, Teucrium montanus, Acinos alpinus, Arenaria serpyllifolia, etc.). These grasslands are similar to Coronillo minimae-Astragaletum monspessulani, as they are markedly pioneer and present numerous xerophilous species; they could be interpreted as a vicariant of Coronillo-Astragaletum on marl-deficient soils. The ecological affinity between these two communities is also highlighted by either EIV NMDS (Figure 3) and growth form CCA (Figure 5) where they show similar positions and trends. The two vegetation types seem to be chorologically quite different (Figure 4) since in Tragopogon samaritani-Bromus erectus communities the Apennine elements are less important and several chorological components (Eurosiberian, Mediterranean and Euro-Mediterranean) are more or less equally represented. Furthermore Coronillo-Astragaletum presents a slightly higher suffrutex cover (WS in Figure 5). Syndynamically, these grasslands tend 
to evolve towards acidophilous shrublands of the class Cytisetea scopario-striati (Angiolini et al. 2007) as indicated by a relevant presence of Cytisus scoparius in the relevés, and subsequently towards meso-acidophilous mixed Quercus spp. dominated woods (Physospermo cornubiensis-Querco petraeae sigmetum) (cfr. De Dominicis et al. 2010).

\subsection{Group B2a3 - FESTUCO TRACHYPHYLLAE- BROMETUM ERECTI ASS. NOVA HOC LOCO (TABLE 1, REL. 37-62; TYPUS REL. n. 49)}

Diagnostic species: Festuca stricta subsp. trachyphylla, Sedum rupestre subsp. rupestre, Aira elegantissima.

Grasslands on scarcely evolved arenaceous soils, often with the presence of outcroppings rocks were recognized at altitudes ranging from 700 to $1040 \mathrm{~m}$ a.s.l. in the mountain of southeastern Tuscan Apennines (Poti Alp, Dogana Mt., Ginezzo Mt. and Catenaia Alp). These communities are characterized by the dominance of Bromus erectus invariably accompanied by Festuca stricta subsp. trachyphylla and by numerous xerophilous species of the Festuco-Brometea class (e.g. Festuca inops, Galium lucidum subsp. lucidum, Allium spherocephalon). This vegetation type appears differentiated by two groups of transgressive species testifying the spatial and dynamical contacts with other vegetation types occurring in the study areas: first group is represented by small succulent suffrutices included in the class Sedo-Scleranthetea such as Sedum rupestre subsp. rupestre, S. sexangulare, and perennial herbs like Rumex acetosella; second group consists of annual subacidophilous, xerophilous and oligotrophic species of the Tuberarietea guttatae class such as Aira elegantissima, Linum tryginum, Cerastium brachypetalum, Briza maxima etc. This vegetation type is here described with the proposal of a new association named Festuco trachyphyllae-Brometum erecti ass. nova hoc loco. The relatively oligotrophic, thermophilous, heliophilous, xerophilous and subacidophilous character of the association is highlighted by the EIV NMDS (Figure 3). According with the ecology of this vegetation type, the chorotype CCA (Figure 4) shows high relevance of Mediterranean and Euro-Mediterranean elements. The growth form CCA (Figure 5) evidences occurrence of annual species in the association. From the vegetation dynamics perspective, in condition of more-evolved soils, these meadows tend to be invaded by woody species such as Erica scoparia,
E. arborea, Calluna vulgaris, Funiperus communis or f. oxycedrus, either forming a mosaic pattern with these shrubs or evolving towards acidophilous vegetation of the class Cytisetea scopario-striatae (see Angiolini et al., 2007). The mature forest steps could be referred to the acidophilous Thyrrenian Q. cerris series (Erico arboreae-Querco cerridis sigmetum and Cephalanthero longifoliae Querco cerridis sigmetum (see De Dominicis et al. 2010).

\subsection{Mesophilous GRASSLANDS OF THE CENTAUREO BRACTEATAE-BROMETUM ERECTI (S.L.) ASSOCIATION}

The $\mathrm{B} 2 \mathrm{~b} 1, \mathrm{~B} 2 \mathrm{~b} 2$ and $\mathrm{B} 2 \mathrm{~b} 3$ groups refer to mesophilous grasslands on evolved soils; these groups include mainly published relevés of Centaureo bracteatae-Brometum erecti association (B2b2), published and unpublished relevés of Ononido masquillerii-Brometum erecti from Sasso di Simone (B2b3), and a slightly separated group of literature and original relevés from several localities of eastern Tuscan Apennines (B2b1). These three groups show several floristic affinities such as the presence of Centaurea jacea subsp. gaudinii $(=C$. bracteata), Dorycnium herbaceum and many other mesophilous species of Bromion/Brometalia syntaxa (see Table 1). These communities appear also ecologically and chorologically quite similar: they are positively related with $\mathrm{N}$ and $\mathrm{U}$ axis (Figure 3), and mostly characterized by Eurasiatic (s.l.) and European chorotypes (Figure 4). Similar trends are also shown by growth form CCA (Figure 5), as they are positively related to a significant presence of perennial herbs. Due to the floristic, ecological and chorological overall affinity, from a syntaxonomic perspective, we prefer to consider all these relevés as belonging to the same association, divided in three distinct subassociations. According to the ICPN (Weber et al. 2000) the priority name to be used is Centaureo bracteatae-Brometum erecti, further articulated in three subassociations: typicum, ononidetosum masquillerii and linetosum cathartici.

\subsubsection{Group B2b1 - Centaureo bracteatae- Brometum erecti linetosum cathartici subass. nova hoc loco (Table 1, rel. 63-77; typus rel. n. 76)}

Diagnostic species of subassociation: Linum catharticum, Leontodon hispidus, Medicago lupulina. 
This vegetation type refers to mesophilous grasslands mainly located in eastern Tuscan Apennines, from Sasso di Simone to Alpe della Luna Mt., generally on low slopes and evolved soils, at altitudes ranging from 770 to $1150 \mathrm{~m}$ a.s.l. The floristic composition is mostly charaterized by mesophilous species of Festuco-Brometea, such as Centaurea jacea subsp. gaudinii, Leucanthemum vulgare, Briza media, etc. and by differential species of Molinio-Arrhenatheretea (Cynosurus cristatus, Trisetaria flavescens, Trifolium pratense, etc.). From an ecological and chorological concern, these communities are very similar to Centaureo bracteataeBrometum typicum and, to lesser extent, to the subass. ononidetosum masquillerii (see Figures 3 and 4). They are also similar to other mesophilous Brometalia associations, such as Trifolio incarnatiBrometum erecti described from Ligurian Apennines (Oberdorfer \& Hofmann 1967). Notwithstanding, these grasslands present some peculiar floristic features, making problematic the attribution to the above mentioned syntaxa; moreover some species, mainly Linum catharticum, Leontodon hispidus, Ononis spinosa, Polygala flavescens, Cirsium tenoreanum, and Carlina utzka, can be considered differential since they are absent or poorly represented in the other two mesophilous communities. Accordingly, based on these plants, the proposal of a new subassociation, named Centaureo bracteatae-Brometum erecti linetosum cathartici subass. nova hoc loco, is herewith advanced. It refers to grazed or sometimes mowed meadows on nutrient-rich soils. Significant presence of Molinio-Arrhenatheretea species indicates the contact of these grasslands with the human-managed meadows in the neighboring. Abandonment of the traditional activities favors the ingression of shrubs (mesophilous Rhamno-Prunetea thickets) and afterwards of mixed oak woods (Aceri obtusati-Querco cerridis sigmetum, Cephalanthero longifoliae-Querco cerridis sigmetum, see De Dominicis et al. 2010).

\subsubsection{Group B2b2 - Centaureo bracteatae-Bro- metum erecti Biondi, Ballelli, Allegrezza, Guitian \& Taffetani 1986 subass. typi- cum (Table 1, rel. 78-91; typus: rel. n. 3, Table 3 in Biondi et al. 1986)}

Diagnostic species: Galium mollugo subsp. erectum, Centaurea scabiosa subsp. scabiosa.

The association was firstly described on marlsandstone substrata of Umbria-Marche Apen- nines, from hilly belt to $900 \mathrm{~m}$ a.s.l. (Biondi et al., 1986). In the original description of the association, Centaurea jacea subsp. gaudinii was considered a characteristic species, but afterwards it was included in the differential species of Polygalo mediterraneae-Bromenion erecti suballiance by Biondi et al. (2005). This vegetation type refers to meadows on evolved substrata, rich in mesophilous species of the Bromion alliance and also in several transgressive plants from MolinioArrhenatheretea class.

From the point of view of vegetation dynamics, with the abandonment of grazing these communities undergo the invasion by shrubs (Funiperus spp., Spartium junceum etc.) and successively evolve towards Quercus cerris/Ostrya carpinifolia/ Fraxinus ornus woods (Biondi et al. 1986). The cluster analysis and Table 1 show that the association is present in two eastern Tuscan sites, always at altitudes lower than $1000 \mathrm{~m}$ a.s.l.: Monte Nero and The National Park of Casentino Forests. The analysis however evidence that this association is probably less widespread in Tuscany than it has been reported in previous studies.

The mesophilous and nitrophilous character of the association is shown by the EIV NMDS (Figure 3); the growth form CCA (Figure 5) and the chorotype CCA (Figure 4) evidence the relevant presence of perennial non-graminoids herbs and the high contribution of Eurasiatic (s.l.) geographic elements, respectively.

\subsubsection{Group B2b3 - Centaureo bracteatae- Brometum erecti ononidetosum masqui- llerii stat. novo (=Ononido masquillierii- Brometum erecti Biondi, Allegrezza, Guitian \& Taffetani 1988 subass. typicum) (Table 1, rel. 92-105; typus rel. n. 5 in Tab. 2 in Biondi et al. 1988)}

Diagnostic species of the subassociation: Ononis masquillieri, Plantago maritima, Scorzonera cana. (In the original description of the association $\mathrm{Do}$ rycnium herbaceum was considered a characteristic species, but afterwards it was included in the differential species of Polygalo mediterraneae-Bromenion erecti suballiance by Biondi et al. 2005).

These communities refer to mesophilous meadows with Bromus erectus and Ononis masquillieri originally described on marl-sandstone clayrich substrata of the Sasso Simone and Simoncello Mts. (Biondi et al. 1988). These grasslands 
are typically in contact with the pioneer association Podospermo cani-Plantaginetum maritimae of the clay badlands, and develop at the head of the badlands, extending also towards areas not directly interested by erosion (Biondi et al. 1988). Ononido masquillieri-Brometum erecti association was interpreted by original Authors as a vicariant of Centaureo bracteatae-Brometum erecti on marl-clay-sandstone substrata. The NMDS and CCA analyses evidence the same features showed by the two other subassociations of Centaureo bracteatae-Brometum erecti: the mesophilic and moderate hygrophilic character of the communities (Figure 3), the relevant portion of perennial herbs among the growth forms (Figure 5) and the important chorological contribution of European and Eurasiatic elements (Figure 4).

\subsection{Group B2b4 - CICHORIUM INTYBUS- BROMUS ERECTUS POST-CULTURAL MESOPHILOUS GRASSLANDS IN HUMAN- DISTURBED AREAS \\ (TABLE 1, REL. 106-116)}

Diagnostic species: Brachypodium rupestre, Bromus erectus, Plantago lanceolata, Cichorium intybus, Calamintha nepeta, Cynosurus echinatus, Trifolium repens, Holcus lanatus, Bromus hordeaceus, Dactylis gomerata, Schedonorus arundinaceus.

In Casentino Valley (eastern Tuscany), from Alpe di Catenaia Mt. to the National Park of Casentino Forests, some grasslands rich in ruderal and human-management related species were detected. The autonomy of this group (B2b4) is highlighted also in the dendrogram derived from cluster analysis (Figure 2). These communities are generally dominated by Bromus erectus and/ or Brachypodium rupestre, and rich in mesophilous species belonging to Bromion alliance with a relevant presence of transgressive species from Molinio-Arrhenatheretea. These features testify the ecological affinities with the above mentioned mesophilous communities. Notwithstanding, it is worth to note that some differential species are present. Some of these species are related to a recent past human management of the meadows (Bromus hordeaceus, Schedonorus arundinaceus, Holcus lanatus, etc.) and others are represented by post-cultural annual or perennial ruderal nitrophilous plants (Cychorium intybus, Galega officinalis, Lolium temulentum, Trifolium angustifolium, etc.) linked to traditional agro-pastoral activities.
The prevalent nitrophilous and mesophilous character of these communities is also shown by the EIV NMDS (Figure 3), whereas the significant presence of cosmopolitan species (see chorotype CCA in Figure 4) testifies the relation with human-management activities.

The diagnostic species of the nine detected groups, based on phi-coefficient, and on the ecological and syntaxonomic relevance here attributed, are reported in Table 2 for an easy comparison.

\subsection{Notes ON THE ATtribution TO HIGHER SYNTAXONOMICAL UNITS}

Recently several complete or partial revisions of the Festuco-Brometea grasslands or papers dealing with these vegetation types, especially in central-southern Apennines, were published and a plethora of syntaxa at every rank was produced. Furthermore, in addition to the syntaxa typically included in the core of the Festuco-Brometea, several papers focused on neighboring classes like Rosmarinetea, Scorzoneretea, Sedo-Scleranthetea, etc. In this work we do not discuss these contact classes, since this topic should be solved using a wide, all-embracing synthesis at European and Mediterranean level. However some considerations are needed in order to classify the vegetation types herewith described within a larger context.

Due to its high suffrutex cover value and to the relevant presence of thermo-xerophilous species, Group A (communities with Bothriochloa ischaemum, Avena barbata and Melica ciliata) can be referred to a transition aspect between the submediterranean grasslands of Festuco-Brometea class and other Mediterranean herbaceous and shrubby classes, particularly Rosmarinetea officinalis.

For the other vegetation types here detected (Group B) it can be inferred that the Bromion species, according to Mucina \& Kolbek (1993), are present in all the relevés, although their presence, both in number and cover values, is less relevant in the left part of Table 1. According to Biondi et al. (2005) the non-calciphilous grasslands of the mesotemperate bioclimatic belt of the northern-central Apennines can be referred to the suballiance Polygalo mediterraneae-Bromenion erecti, which has as type the association Centaureo bracteatae-Brometum erecti. Biondi et al. 
(2005) highlighted that this suballiance includes some pioneer grassland types, like Coronillo-Astragaletum association, together with more mesophilous communities, like Centaureo-Brometum and similar aspects. Our relevés belonging to group B are separated by the cluster analysis in two main subgroups, the B1 and B2 clusters. The latter is further divided in two subgroups: B2a grasslands (Coronillo-Astragaletum, Festuco trachyphyllae-Brometum, Tragopogon samaritanus-Bromus erectus communities) are more pioneer and grow on shallow and less evolved soils, while B2b communities (Centaureo bracteatae-Brometum subass. typicum, subass. ononidetoum masquillerii, subass. linetosum cathartici and Cichorium intybus-Bromus erectus post-cultural grasslands) are more mesophilous and typical of deeper and evolved soils. Due to their ecological and floristic features, B2 communities can be attributed to Polygalo mediterraneae-Bromenion erecti suballiance, with both its pioneer (B2a) and its mesophilous aspects (B2b). On the contrary, B1 grasslands (Plantago argentea-Carex caryophyllea communities) share with B2a some similar ecological aspects (pioneer features, non-evolved soils, etc.) but, from a strictly floristic perspective, they appear impoverished in diagnostic species of higher syntaxa; however, we also refer these communities to Polygalo mediterraneae-Bromenion erecti and Bromion, but this attribution should be confirmed by further field data and analyses.

Regarding the attribution at the order level, several syntaxonomical disputations have been more or less recently produced by several authors about the ecological requirements and the nomenclatural validity of the order Brometalia erecti (e.g. Dengler 2003, 2004, Dengler et al. 2003, Mucina et al. 2009, Terzi 2011, Di Pietro 2011, Biondi \& Galdenzi 2012, Becker et al. 2012). In this work we use the name Brometalia erecti Koch 1926 according to Biondi \& Galdenzi (2012), waiting for a definitive sentence of the ICPN nomenclature Committee (Weber et al. 2000) about its rejection and substitution by Brachypodietalia pinnati Korneck 1974, as suggested by Dengler et al. (2003) and Mucina et al. (2009).

\section{SyNTAXONOMIC SCHEME}

Festuco-Brometea Br.-B1. et R. Tx. ex Klika et Hadač 1944

Brometalia erecti W. Koch 1926

Bromion erecti W. Koch 1926

Polygalo mediterraneae-Bromenion erecti Biondi, Allegrezza et Zuccarello 2005

Coronillo minimae-Astragalaetum monspessulani Biondi et Ballelli in Biondi et al. 1985

seslerietosum italicae Zanotti, Ubaldi \& Puppi 1995

Tragopogon samaritani-Bromus erectus comm. Plantago argentea-Carex caryohyllaea comm.

Festuco trachyphyllae-Brometum erecti ass. nova

Centaureo bracteatae-Brometum erecti Biondi, Ballelli, Allegrezza, Guitian et Taffetani 1986.

subass. typicum

subass ononidetosum masquillierii (Biondi, Ballelli, Allegrezza, Guitian et Taffetani 1986) stat. novo

subass. linetosum cathartici subass. nova

Cichorium intybus-Bromus erectus comm.

\section{ACKNOWLEDGEMENT}

Thanks are due to Jürgen Dengler and Ladislav Mucina for providing articles and useful information. Research was supported by a grant from the University of Florence (Fondi Ateneo ex 60\%). 


\section{REFERENCES}

Angiolini, C., Riccucci, C. \& De Dominicis, V. 2003: Grasslands of the order Brometalia erecti Br.-Bl. 1936 on Antiapennine calcareous massifs in central-southern Tuscany (central Italy). Lazaroa 24: 61-8.

Angiolini, C., Foggi, B., Viciani, D. \& Gabellini, A. 2007: Acidophytic shrublands in the northwest of the Italian peninsula: Ecology, chorology and syntaxonomy. Plant Biosystems 141: 134-163.

Angiolini, C., Gabellini, A., Frignani, F., Giallonardo, T. \& De dominicis, V. 2009: Contributo alla conoscenza della vegetazione della Riserva naturale provinciale "Monte Penna" (Grosseto, Toscana meridionale). Atti Società Toscana di Scienze Naturali, Memorie, Serie B, 115 (2008): 1-20

Arrigoni, P.V. 2003: Flora e vegetazione del Colle di Monsummano in Toscana. Parlatorea 6: 5-47.

Arrigoni, P.V. \& Bartolini, L. 1997: Documenti per la carta della vegetazione della Calvana di Prato in Toscana. Parlatorea 2: 101-123.

Arrigoni, P.V., Foggi, B., Bechi, N. \& Ricceri, C. 1997: Documenti per la carta della vegetazione del Monte Morello (Provincia di Firenze). Parlatorea 2: 73-100.

Arrigoni, P.V., Ricceri, C. \& Mazzanti, A. 1983: La vegetazione serpentinicola del Monte Ferrato di Prato in Toscana. Arti graf. Prioreschi, Catena di Quarrata, Pistoia, 27 pp.

Arrigoni, P. V. 1983: Aspetti corologici della flora sarda. Lavori della Società Italiana di Biogeografia, n.s., 8: 81-109.

Arrigoni, P. V. 1996: A classification of plant growth form aplicable to the Floras and Vegetation types of Italy. Webbia 50(2): 193-203.

Barcella, M. \& Assini, S. 2013: Montane grasslands in the northern Apennine: syntaxonomy, syncorology and synecology. Hacquetia (in press).

Becker, T., Schmiege, C., Bergmeier, E., Dengler, J. \& Nowak, B. 2012: Nutrient-poor grasslands on siliceous soil in the lower Aar valley (Middle Hesse, Germany) - Neglected vegetation types in the intersection range of four classes. Tuexenia 32: 281-318.

Biondi, E., Allegrezza, M., Guitian, J. \& Taffetani, F. 1988: La vegetazione dei calanchi di Sasso Simone e Simoncello (Appennino tosco- marchigiano). Braun-Blanquetia 2: 105-115.

Biondi, E., Allegrezza, M. \& Zuccarello, V. 2005: Syntaxonomic revision of the Apennine grasslands belonging to Brometalia erecti, and an analysis of their relationships with the xerophilous vegetation of Rosmarinetea officinalis (Italy). Phytocoenologia 35(1): 129-164.

Biondi, E., Ballelli, S., Allegrezza, M. \& Zuccarello, V. 1995: La vegetazione dell'ordine Brometalia erecti Br.-Bl. 1936 nell'Appennino (Italia). Fitosociologia 30: 3-45.

Biondi, E., Ballelli, S. \& Principi, D. 1985: Sur les pelouses seches des substrats marneux- arenaces de l'Apennin septentrional (Italie). Documents Phytosociologiques, N.S., 9: 351-357. Camerino.

Biondi, E., Ballelli, S., Allegrezza, M., Guitian, J. \& Taffetani, F. 1986: Centaureo bracteatae-Brometum erecti ass. nova dei settori marnoso-arenacei dell'Appennino centrale. Documents Phytosociologiques, N.S., 10 (2): 117-126. Camerino.

Biondi, E. \& Galdenzi, D. 2012: Phytosociological analysis of the grasslands of Montagna dei Fiori (central Italy) and syntaxonomic review of the class Festuco-Brometea in the Apennine. Plant Sociology 49(1): 91-112.

Biondi, E. 2005: Vegetation and priority habitats. In: Blasi, C., Boitani, L., La Posta, S., Manes, F. \& Marchetti, M., Biodiversity in Italy. Palombi ed. Roma, 202-219 pp.

Braun-Blanquet, J. 1932: Plant Sociology. Mac Graw Hill Book Company, New York.

Braun-Blanquet, J. 1964: Pflanzensoziologie. Springer, Wien

Carmignani, L. \& Lazzarotto, A. (Coordinators) 2004: Carta Geologica della Toscana/Geological Map of Tuscany (Italy) $1: 250000$. Regione Toscana, Direzione delle Politiche Territoriali e Ambientali-Servizio Geologico.

Casini, S. \& De Dominicis, V. 1999: Memoria illustrativa per la carta della vegetazione del Chianti (scala 1:50.000). Studio fitosociologico. Parlatorea 3: 79-106.

Castelli, M. 1995: Brometi del versante padano dell'Appennino Ligure-Piemontese (Italia). Fitosociologia 30: 51-90.

Castelli, M., Biondi, E. \& Ballelli, S. 2001: La vegetazione erbacea, arbustiva e preforestale del piano montano dell'Appennino Piemontese (Valli Borbera e Curone - Italia). Fitosociologia 38(1): 125-151.

Chytrý, M., Tichý, L., Holt, J. \& Botta-Dukát, Z. 
2002: Determination of diagnostic species with statistical fidelity measures. Journal of Vegetation Science 13: 79-90.

Chytrý, M., Hoffmann, A. \& Novák, J. 2007: Suché trávníky (Festuco-Brometea) [Dry grasslands (Festuco-Brometea)]. - In: Chytrý, M. (ed.), Vegetace České republiky. 1. Travinná a keříčková vegetace [Vegetation of the Czech Republic. 1. Grassland and heathland vegetation], 371-497 pp., Academia, Praha.

Chytrý, M. (ed.) 2007: Vegetace České republiky. 1. Travinná a keříčková vegetace [Vegetation of the Czech Republic. 1. Grassland and heathland vegetation], Academia, Praha, CZ.

Conti, F., Abbate, G., Alessandrini, A. \& Blasi, C., 2005: An annotated Checklist of the Italian Vascular Flora. Min. Ambiente e Tutela Territ., Dip. Biol. Veg. Univ. "La Sapienza". Palombi Ed., Roma.

Conti, F., Alessandrini, A., Bacchetta, G., Banfi, E., Barberis, G., Bartolucci, F., Bernardo, L., Bonacquisti, S., Bouvet, D., Bovio, M., Brusa, G., Del Guacchio, E., Foggi, B., Frattini, S., Galasso, G., Gallo, L., Gangale, C., Gottschlich, G., Grünanger, P., Gubellini, L., Iriti, G., Lucarini, D., Marchetti, D., Moraldo, B., Peruzzi, L., Poldini, L., Prosser, F., Raffaelli, M., Santangelo, A., Scassellati, E., Scortegagna, S., Selvi, F., Soldano, A., Tinti, D., Ubaldi, D., Uzunov, D. \& Vidali, M. 2007: Integrazioni alla checklist della flora vascolare italiana. Natura Vicentina 10 (2006): 5-74.

De Dominicis, V., Angiolini, C. \& Gabellini, A. 2010: Le serie di vegetazione della regione Toscana. In: Blasi, C. (ed.) La vegetazione d'Italia, 204-229 pp. Palombi and Partner s.r.l., Roma.

De Dominicis, V., Gabellini, A., Viciani, D., Morrocchi, D. \& Gonnelli V. 2002: Contributo alla conoscenza vegetazionale della Riserva Naturale del Sasso di Simone (Toscana orientale). Atti Società Toscana di Scienze Naturali, Memorie, Serie B 108 (2001): 7-26.

Dengler, J., Berg, C., Eisenberg, M., Isermann, M., Jansen, F., Koska, I., Lobel, S., Manthey, M., Pazolt, J., Spangenberg, A., Timmermann, T. \& Wollert, H. 2003: New descriptions and typifications of syntaxa within the project 'Plant communities of MecklenburgVorpommern and their vulnerability'. Part I - Feddes Repertorium 114: 587-631.

Dengler, J., Berg, C. \& Jansen, F. 2005: New ideas for modern phytosociological monographs.
Annali di Botanica Roma, N. S. 5: 193-210.

Dengler, J., Chytrý, M. \& Ewald, J. 2008: Phytosociology. In: Jørgensen, S. E. \& Fath, B. D. (eds.): Encyclopedia of ecology. Elsevier, Oxford, 2767-2779 pp.

Dengler, J., Rūsina, S., Boch, S., Bruun, H. H., Diekmann, M., Dierßen, K., Dolnik, C., Dupré, C., Golub, V. B., Grytnes, J.-A., Helm, A., Ingerpuu, N., Löbel, S., Pärtel, M., Rašomavičius, V., Tyler, G., Znamenskiy, S. R., \& Zobel, M. 2006: Working group on dry grasslands in the Nordic and Baltic region-Outline of the project and first results for the class Festuco-Brometea. Annali di Botanica Roma, N.S., 6: 1-28.

Dengler, J. 2004: Klasse: Festuco-Brometea Br.-Bl. \& Tx. ex Klika \& Hadač 1944 - Basiphile Magerrasen und Steppen im Bereich der submeridionalen und temperaten Zone - In: Berg, C., Dengler, J., Abdank, A. \& Isermann, M. (eds.): Die Pflanzengesellschaften Mecklenburg-Vorpommerns und ihre Gefahrdung - Textband. Weissdorn, Jena, 327-335 pp.

Di Pietro, R. 2011: New dry grassland associations from the Ausoni-Aurunci mountains (Central Italy) - Syntaxonomical updating and discussion on higher rank syntax. Hacquetia 10(2): 183-231.

Ellenberg, H., Weber, H.E., Düll, R., Wirth, V. \& Werner, W. 2001: Zeigerwerte von Pflanzen in Mitteleuropa. Scripta Geobotanica 18, 3. $262 \mathrm{pp}$.

Foggi, B. \& Venturi, E. 2009: Gli habitat meritevoli di conservazione della provincia di Prato. In: Fancelli, E., (a cura di) 2009, Biodiversità in Provincia di Prato. Vol. 4: Habitat. Editrice Le Balze \& Effigi Edizioni, 227 pp.

Géhu, J.M. 1988: L'analyse symphytosociologique et géosymphytosociologique de l'éspace. Théorie et métodologie. Colloques Phytosociologiques 17: 11-46.

Gennai, M. 2011: Il paesaggio vegetale della provincia di Pistoia. Tesi di Dottorato in Biosistematica ed Ecologia vegetale, Scuola di Dottorato "Ubaldo Montelatici", XXIV ciclo, Università degli Studi di Firenze.

Hammer, Ø., Harper, D.A.T. \& Ryan, P.D. 2001: PAST Paleontological Satistics Software Package for Education and Data Analysis http:// palaeo_electronica.org.

Korneck, D. 1974: Xerothermvegetation von Rheinland- Pfalz und Nachbargebieten. Schriftenreihe für Vegetationskunde 7: 1-196. 
Lastrucci, L., Foggi, B., Raffaelli, M., Benesperi, R., Gonnelli, V., Zinetti, F., Principi, G. \& Cavazzoni, D. 2009: Contributo alla conoscenza naturalistica dell'Area Naturale Protetta di Interesse Locale (ANPIL) "Serpentine di Pieve S. Stefano (Arezzo, Toscana). Bollettino del Museo Regio di Scienze Naturali Torino 27(1): 101-151.

Mucina, L. \& Kolbek, J. 1993: Festuco-Brometea In: Mucina, L., Grabherr, G. \& Ellmauer, T. (eds.). Die Pflanzengesellschaften Osterreichs - Teil I: Anthropogene Vegetation. Fischer, Jena, 420-492 pp.

Mucina, L., Dengler, J., Bergmeier, E., Čarni, A., Dimopoulos, P., Jahn R., \& Matevski, V. 2009: New and validated high-rank syntax from $\mathrm{Eu}-$ rope. Lazaroa 30: 267-276.

Oberdorfer, E. 1978: Süddeutsche Pflanzengesellschaften - Teil II. G. Fischer Verlag. Stuttgart, New York. 355 pp.

Oberdorfer, E. \& Hofmann, A. 1967: Beitrag zur Kenntnis der Vegetation des Nordapennin. Beitr. Naturk. Forsch. Südwestdeutschl. 26(1): 83-139.

Pignatti, S. 2005: Valori di bioindicazione delle piante vascolari della Flora d'Italia. (Bioindicator values of vascular plants of the Flora of Italy). Braun-Blanquetia 39: 3-95.

Podani J. 2002: SYNTAX V. Scientia Publishing, Budapest.

Rivas-Martínez, S., Díaz, T. E., Fernández-González, F., Izco, J., Loidi, J., Lousã, M. \& Penas, Á. 2002: Vascular plant communities of Spain and Portugal. Addenda to the Syntaxonomical checklist of 2001. Itinera Geobotanica 15 (1-2): 5-922.

Rivas-Martínez, S., Díaz, T.E., Prieto, J.A., Loidi, J. \& Penas, A. 1991: Festuco hystricis-Ononidetea striatae y Rsomarinetea officinalis, clases de vegetación indipendientes. Itinera Geobotanica 5: 505-516.

Royer, J.M. 1991: Synthèse eurosibérienne, phytosociologique et phytogeographique des FestucoBrometea. Dissertationes Botanicae 178: 1-296.

Takhtajan, A. 1986: Floristic Regions of the World. Transl. by T.J. Crovello and ed. by A. Cronquist. University of California Press, ISBN, 0520040279, Berkeley.

Terzi, M. 2011: Nomenclatural revision of the order Scorzonero-Chrysopogonetalia. Folia Geobotanica 46: 411-444.

Tichý L., 2002: JUICE, software for vegetation classification. Journal Vegetation of Sciences,
13: 451-453. (www.sci.muni.cz/botany/juice)

Viciani, D. \& Gabellini, A. 2006: La vegetazione dell'Alpe di Catenaia (Arezzo, Toscana) ed i suoi aspetti di interesse botanico- conservazionistico. Webbia 61(1): 167-191.

Viciani, D. \& Gabellini, A. 2013: Contributo alla conoscenza della vegetazione della Foresta Regionale "Monte Arsenti - Poggi di Prata" (Toscana centro-meridionale). Informatore Botanico Italiano 45 (1) (in press).

Viciani, D., Foggi, B., Gabellini, A. \& Rocchini, D. 2002a: Contributo alla conoscenza delle praterie su substrati ultramafici dell'Alta Valtiberina (Toscana orientale, Italia). Fitosociologia 39 (1): 127-134.

Viciani, D., Gabellini, A., Gonnelli, V. \& De Dominicis, V. 2002b: La vegetazione della Riserva Naturale Alpe della Luna (Arezzo, Toscana) ed i suoi aspetti di interesse botanico-conservazionistico. Webbia 57 (1): 153-170.

Viciani, D., Gabellini, A., Gonnelli, V. \& De Dominicis, V. 2004: La vegetazione della Riserva Naturale Alta Valle del Tevere-Monte Nero (Arezzo, Toscana) ed i suoi aspetti di interesse botanico-conservazionistico. Atti Società Toscana di Scienze Naturali, Memorie, Serie B, 109 (2002): 11-25.

Weber, H.E., Moravec, J. \& Theurillat, J.-P. 2000: International Code of Phytosociological Nomenclature. Journal of Vegetation Science 11: 739-768.

Zanotti, A.L., Ubaldi, D. \& Puppi, G. 1995: Ricerche sulla vegetazione dei prati aridi e semiaridi nel Bolognese e in Romagna. Archivio Geobotanico 1: 91-100.

Zanotti, A.L., Ubaldi, D., Puppi, G. \& Sirotti, M. 1998: Osservazioni fitosociologiche sulle praterie montane dell'area del Monte Nero (Appennino Ligure-Emiliano). Archivio Geobotanico 4 (2): 181-192). 


\section{APPENDIX 1}

\section{Published relevés of Table 1 - References}

Relevés n. 10-23: Biondi et al. (1985); relevés n. 25, 26, 30, 69-72: Viciani et al. (2002b); relevés n. 61, 108: Viciani \& Gabellini (2006); relevé n. 77: Viciani et al. (2004); relevés n. 78-90: Biondi et al. (1986); relevés n. 93-100: Biondi et al. (1988).

\section{Unpublished relevés of Table 1 - Geolocalization}

For each unpublished relevé the number is followed by the coordinates UTM WGS84 $\mathrm{x}$ and $\mathrm{y}$.

$$
\begin{array}{rr}
1-659662,4852937 ; & 2-660345,4853201 ; \\
3-660257,4853168 ; & 4-659881,4852928 ; \\
5-637368,4874761 ; & 6-637339,4874841 ; \\
7-637350,4874812 ; & 8-637694,4874598 ; \\
9-637656,4874594 ; & 27-740026,4848006 ; \\
28-738856,4848690 ; & 29-738914,4848706 ; \\
37-745853,4809728 ; & 38-744996,4809887 ; \\
39-744936,4808833 ; & 40-738874,4818673 ; \\
41-738663,4818385 ; & 42-739159,4818317 ; \\
43-738752,4818426 ; & 44-739901,4817797 ; \\
45-746206,4797400 ; & 46-746455,4797899 ; \\
47-746466,4797875 ; & 48-745197,4809930 ; \\
49-750551,4795942 ; & 50-744982,4808825 ; \\
51-751133,4795180 ; & 52-749793,4796656 ; \\
53-748924,4796954 ; & 54-744796,4810487 ; \\
55-750008,4796388 ; & 56-750287,4796144 ; \\
57-750543,4795946 ; & 58-749591,4796832 ; \\
59-749733,4796704 ; & 60-744974,4808775 ; \\
63-751937,4841104 ; & 67-750129,4841617 ; \\
73-752206,4840983 ; & 74-751933,4841009 ; \\
75-752196,4841101 ; & 76-752379,4840926 ; \\
91-737834,4845440 ; & 101-765038,4850206 ; \\
102-763508,4850767 ; & 103-766914,4848553 ; \\
104-762576,4850272 ; & 105-762806,4850414 ; \\
106-765808,4849460 ; & 107-766555,4849632 ; \\
109-724041,4850393 ; & 110-739529,4848657 ; \\
111-737784,4849523 ; & 112-721743,4854598 ; \\
113-722340,4852913 ; & 114-721682,4854550 ; \\
115-722928,4853141 ; & 116-736694,4848427 ;
\end{array}
$$

\section{Sporadic species of Table 1}

Rel. 1: Aegilops neglecta Req. ex Bertol. 1, Odontites sp., 1, Trachynia distachya (L.) Link.; Ril. 2: Dianthus balbisii Ser. subsp. balbisii, +, Spar- tium junceum L., 2; Rel. 3: Linaria vulgaris Mill. subsp. vulgaris, +; Rel. 5: Minuartia hybrida (Vill.) Shischk. subsp. hybrida, +; Rel. 6: Sedum acre L., 2; Rel. 9: Trifolium sp., +; Taraxacum erythrosperma (group), 1; Rel. 22: Trifolium dubium Sibth., +, Anagallis arvensis L. s.l., +, Arenaria bertolonii Fiori, +, Chaenorhinum minus (L.) Lange subsp. Minus, +, Festuca centro-apenninica (Markgr.-Dann.) Foggi, F. Conti \& Pignatti, +, Cytisus sessilifolius L., +; Rel. 23: Orchis purpurea L., +; Rel. 27: Polygala major Jacq., +, Genista januensis Viv., +; Rel. 28: Polygala major Jacq., +; Rel. 29: Sedum acre L., 1; Rel. 30: Trifolium dubium Sibth., +, Anagallis arvensis L. s.l., +, Chaenorhinum minus (L.) Lange subsp. minus, +, Arenaria bertolonii Fiori, +, Trachynia distachya (L.) Link, 1, Festuca centro-apenninica (Markgr.-Dann.) Foggi, F. Conti \& Pignatti, 1; Rel. 31: Deschampsia flexuosa (L.) Trin. s.l., +; Rel. 33: Epilobium dodonaei Vill., +, Securigera varia (L.) Lassen, +; Rel. 34: Dianthus seguieri Vill. subsp. seguieri, +; Rel. 37: Scabiosa holosericea Bertol., +, Crupina crupinastrum (Moris) Vis., +, Cuscuta sp., +; Rel. 38: Geranium dissectum L., +, Rubus hirtus Waldst. \& Kit., +; Rel. 40: Juniperus oxycedrus L. subsp. oxycedrus, 1, Crepis capillaris (L.) Wallr., +, Vicia tetrasperma (L.) Schreb., +; Rel. 42: Ophrys bertolonii Moretti, +, Alyssum campestre (L.) L. s.l., +; Rel. 43: Spartium junceum L., +, Astragalus hamosus L., +, Catapodium rigidum (L.) C.E. Hubb. s.l., +, Cynoglossum creticum Mill., r, Valerianella muricata (Stev. ex M. Bieb.) J.W. Loudon, +; Rel. 44: Ophrys bertolonii Moretti, +, Alyssum campestre (L.) L. s.l.; Rel. 45: Vicia peregrina L., +, Cistus creticus L. subsp. eriocephalus (Viv.) Greuter \& Burdet, +; Rel. 46: Silene gallica L., +, Sonchus oleraceus L., 1; Rel. 48: Scabiosa holosericea Bertol., +, Knautia integrifolia (L.) Bertol. subsp. integrifolia, 1; Rel. 50: Vicia bithynica (L.) L., +; Rel. 51: Filago minima (Sm.) Pers., +, Galium divaricatum Pourr. ex Lam., +; Rel. 52: Hypochaeris glabra L., +, Scleranthus annuus L., +; Rel. 54: Minuartia hybrida (Vill.) Shischk. subsp. hybrida, +, Erica scoparia L. subsp. scoparia, +, Scleranthus perennis L. s.l., +; Rel. 55: Asphodelus macrocarpus Parl. subsp. macrocarpus, 2, Ranunculus millefoliatus Vahl., +, Linaria vulgaris Mill. subsp. vulgaris, +, Narcissus poëticus L. s.l., 2, Campanula trachelium L. subsp. trachelium, 2, Cardamine hirsuta L., +, Festuca trichophylla (Ducros ex Gaudin) K. Richt. subsp. asperifolia (St.-Yves) Al-Bermani, +, Neotinea ustulata (L.) 
R.M. Bateman, Pridgeon \& M.W. Chase, +, Oreoselinum nigrum Delarbre, 1, Vicia incana Gouan, 1; Rel. 56: Ranunculus millefoliatus Vahl, 1, Veronica arvensis L., +; Rel. 57: Geranium dissectum L., +, Veronica arvensis L., +, Taraxacum fulvum Raunk., +; Rel. 58: Asphodelus macrocarpus Parl. subsp. macrocarpus, 2, Luzula forsteri (Sm.) DC., r, Anthericum liliago L., +; Rel. 59: Hypochaeris glabra L., +, Luzula forsteri (Sm.) DC., r, Silene gallica L., +, Anthemis cotula L., + , Consolida regalis Gray s.l., r, Lupinus albus L. subsp. albus, +, Vulpia bromoides (L.) Gray, +; Rel. 60: Rhinanthus alectorolophus (Scop.) Pollich, 2, Dianthus deltoides L. subsp. deltoides, r; Rel. 61: Dianthus armeria L. subsp. armeria, +, Galium parisiense L., +; Rel. 62: Dianthus armeria L. subsp. armeria, +, Galium parisiense L., +, Odontites sp., +; Rel. 63: Trifolium strictum L., +, Vicia peregrina L., +, Saxifraga tridactylites L., +; Rel. 64: Helleborus bocconei Ten. s.l., +; Rel. 66: Sulla coronaria (L.) Medik., 1; Rel. 67: Crepis vesicaria L. s.l., +, Trifolium strictum L., +, Veronica arvensis L., +; Rel. 68: Poa annua L., +, Anthemis arvensis L. s.l., +, Cervaria rivinii Gaertn., +, Dactylorhiza sambucina (L.) Soó, +; Rel. 69: Colchicum lusitanum Brot., +, Ostrya carpinifolia Scop., +; Rel. 70: Acer opalus Mill. subsp. obtusatum (Waldst. \& Kit. ex Willd.) Gams, +, Astragalus glycyphyllos L., +, Crataegus monogyna Jacq., +, Homalotrichon pubescens (Huds.) Banfi, Galasso \& Bracchi s.l., +, Allium vineale L., +; Rel. 71: Dactylorhiza maculata (L.) Soó, +, Homalotrichon pubescens (Huds.) Banfi, Galasso \& Bracchi s.l., +, Poa annua L., +; Rel. 72: Acer opalus Mill. subsp. obtusatum (Waldst. \&
Kit. ex Willd.) Gams, +, Astragalus glycyphyllos L., +, Dactylorhiza maculata (L.) Soó, +, Listera ovata (L.) R. Br., +; Rel. 74: Dipsacus fullonum L., +, Galeopsis angustifolia Hoffm. subsp. angustifolia, +, Aremonia agrimonoides (L.) DC. subsp. agrimonoides, +, Primula vulgaris Huds. subsp. vulgaris, +; Rel. 75: Trifolium sp., r; Rel. 76: Galeopsis angustifolia Hoffm. subsp. angustifolia, +; Rel. 84: Minuartia hybrida (Vill.) Shischk. subsp. hybrida, +; Rel. 85: Himantoglossum adriaticum H. Baumann, +, Ophrys apifera L., 1, Aceras anthropophorum (L.) R. Br., 1; Rel. 91: Crataegus monogyna Jacq., +, Marrubium incanum Desr., +, Equisetum arvense L. subsp. arvense, +; Rel. 92: Polygala vulgaris L. subsp. vulgaris, +, Daphne oleoides Schreb., r; Rel. 105: Gaudinia fragilis (L.) P. Beauv., +; Rel. 107: Cruciata glabra (L.) Ehrend., +, Polygala alpestris Rchb., +; Rel. 108: Trifolium incarnatum L. subsp. molinerii (Hornem.) Ces., +, Barbarea stricta Andrz., +, Cerastium arvense L. subsp. arvense, +; Rel. 109: Crepis neglecta L., +, Galega officinalis L., +, Verbena officinalis L., +, Avena sterilis L. s.l., 1, Dipsacus fullonum L., +, Helminthotheca echioides (L.) Holub, 1, Medicago arabica (L.) Huds., +, Trifolium striatum L., +; Rel. 110: Lolium temulentum L. subsp. temulentum, +, Rhinanthus alectorolophus (Scop.) Pollich, +, Marrubium incanum Desr., +, Danthonia decumbens (L.) DC. subsp. decumbens, +, Geranium molle L., +; Rel. 114: Crepis neglecta L., +, Cirsium vulgare (Savi) Ten., +, Knautia integrifolia (L.) Bertol. subsp. integrifolia, +, Torilis japonica (Houtt.) DC., +; Rel. 115: Filago germanica (L.) Huds., +, Althaea hirsuta L., +; Rel. 116: Vulpia ciliata Dumort., r. 
Table 1: Published and unpublished relevés of the grasslands on sandstone and marl-clay-sandstone substrata.

Relevé n.

Altitude (m a.s.1.)

Aspect

Total cover $(\%)$

Slope $\left(^{\circ}\right)$

Area $\left(\mathrm{m}^{2}\right)$

Site abbreviation

Typus (T)

Relevés from literature (for references see Appendix 1)

Number of the relevé in the original publication

Number of the table in the original publication

Botriochloa ischaemum-Melica ciliata comm.

Avena barbata Pott ex Link

Melica ciliata L. s.1.

Galactites tomentosus Moench

Carthamus lanatus L. subsp. lanatus

Bothriochloa ischaemum (L.) Keng

Onobrychis caput-galli (L.) Lam.

Centaurea deusta Ten.

Echium vulgare L.

Tragopogon porrifolius L. s.1.
Globularia punctata Lapeyr

$\begin{array}{lllllllllllllllllllll}1 & 2 & 3 & 4 & 5 & 6 & 7 & 8 & 9 & 10 & 11 & 12 & 13 & 14 & 15 & 16 & 17 & 18 & 19 & 20 & 21\end{array}$

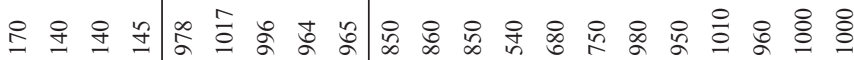

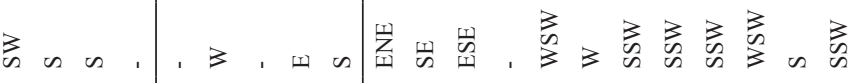
\begin{tabular}{llll|lllllllllllllllll}
80 & 50 & 70 & 80 & 100 & 85 & 100 & 100 & 100 & 90 & 90 & 90 & 90 & 20 & 90 & 90 & 80 & 85 & 30 & 90 & 50
\end{tabular} \begin{tabular}{llll|lllll|llllllllllll}
5 & 20 & 25 & - & - & 5 & - & 3 & 3 & 30 & 10 & 50 & - & 70 & 50 & 30 & 30 & 20 & 25 & 30 & 40
\end{tabular} \begin{tabular}{llll|llllllllllllllllll}
10 & 10 & 15 & 15 & 10 & 10 & 10 & 10 & 10 & 15 & 20 & 20 & 15 & 20 & 15 & 20 & 20 & 10 & 15 & 20 & 10
\end{tabular} AT AT AT AT SP SP SP SP SP

Transgressive species from Rosmarinetea and other Mediterranean classes Asparagus acutifolius

Teucrium capitatum L. subsp. capitatum

Crupina vulgaris Cass.

Dorycnium hirsutum

Micromeria graeca (L.) Benth. ex Rchb. s.l.

Cistus monspeliensis L.

Plantago argentea-Carex caryophyllea comm.

Plantago argentea Chaix subsp. argentea

Koeleria lobata (M. Bieb.) Roem. \& Schult.

Bromus rubens L.

Centaurea arrigonii Greuter

Poa bulbosa L.

Aira caryophyllea L. subsp. caryophyllea

Cerastium pumilum

Medicago minima (L.) Bartal.

Hypochaeris radicata $\mathrm{L}$.

Aphanes arvensis L.

Geranium rotundifolium L.

Gnaphalium sylvaticum L.

Coronillo minimae-Astragaletum monspessulani

Astragalus monspessulanus L. subsp. monspessulanus

Coronilla minima L.

Linum tenuifolium $\mathrm{L}$.

Fumana procumbens (Dunal) G.et G.

Leontodon rosani (Ten.) DC.

Sesleria italica (Pamp.) Ujhelyi (diff. of subass. seslerietosum italicae)

Tragopogon samaritani-Bromus erectus comm.

Thymus pulegioides L. s.l.

Arenaria serpyllifolia L. s.1.

Silene vulgaris (Moench) Garcke s.1.

Anthyllis vulneraria L. s.1.

Teucrium montanum L.

Tragopogon samaritani Heldr. \& Sart. ex Boiss.

Crepis staticifolia (All.) Galasso, Banfi \& Soldano $\begin{array}{lllllllllllllll}\mathrm{x} & \mathrm{x} & \mathrm{x} & \mathrm{x} & \mathrm{x} & \mathrm{x} & \mathrm{x} & \mathrm{x} & \mathrm{x} & \mathrm{x} & \mathrm{x} & \mathrm{x}\end{array}$

$\begin{array}{llllllllllll}1 & 2 & 6 & 7 & 3 & 8 & 10 & 12 & 14 & 5 & 9 & 13\end{array}$

\begin{tabular}{llllllllllll}
1 & 1 & 1 & 1 & 1 & 1 & 1 & 1 & 1 & 1 & 1 & 1 \\
\hline
\end{tabular}


Tabela 1: Objavljeni in neobjavljeni popisi travišč na podlagi iz peščenjaka in laporasto-glinastega peščenjaka.

\begin{tabular}{llllllllllllllllllllllllllllllllllllll}
22 & 23 & 24 & 25 & 26 & 27 & 28 & 29 & 30 & 31 & 32 & 33 & 34 & 35 & 36 & 37 & 38 & 39 & 40 & 41 & 42 & 43 & 44 & 45 & 46 & 47 & 48 & 49 & 50 & 51 & 52 & 53 & 54 & 55 & 56 & 57 & 58 & 59 \\
\hline
\end{tabular}

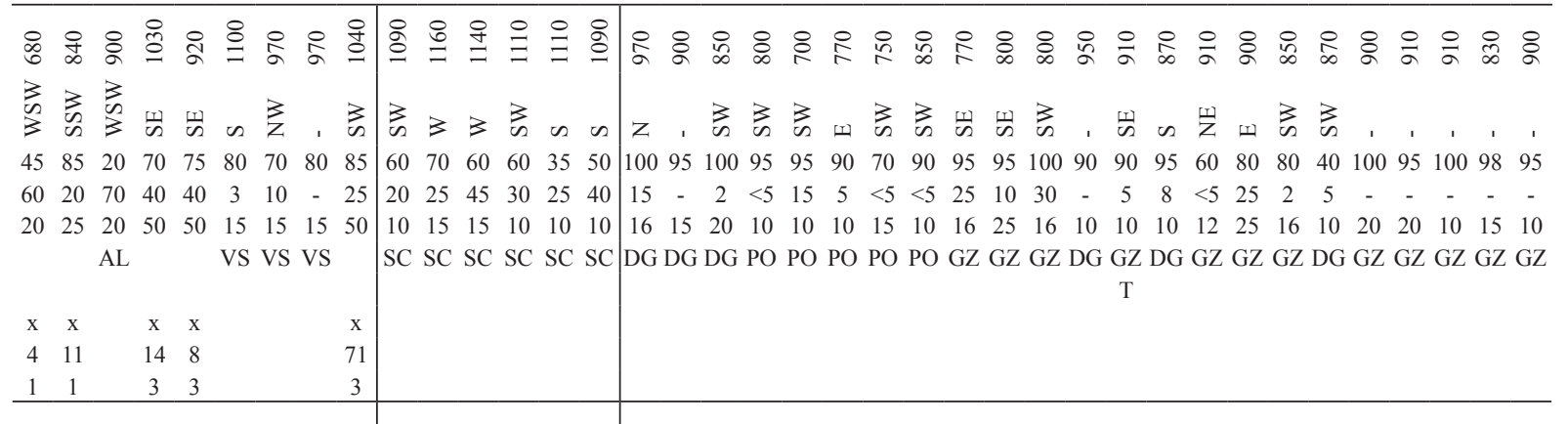

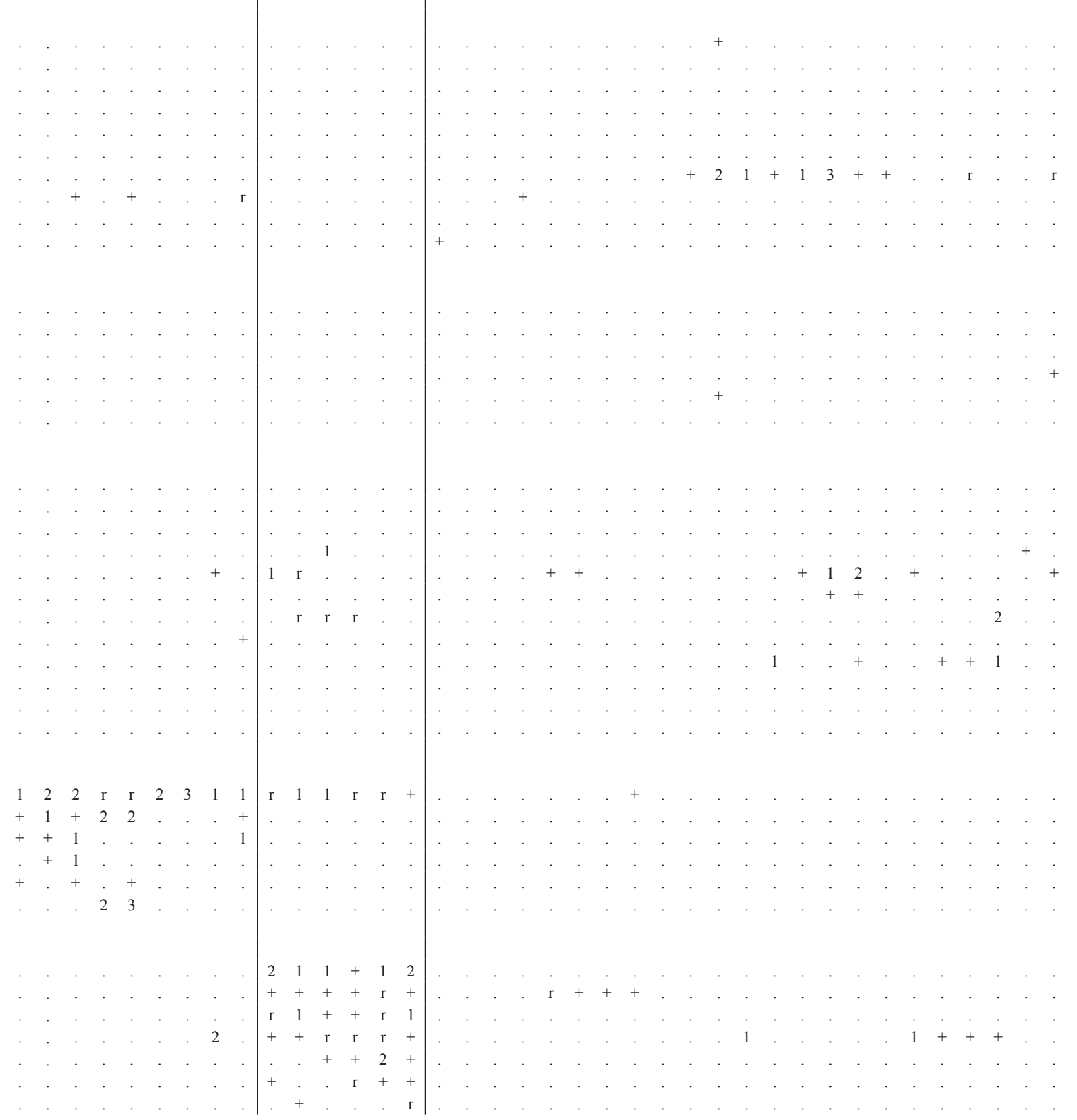


Aspect

Total cover $(\%)$

Slope $\left({ }^{\circ}\right)$

Area $\left(\mathrm{m}^{2}\right)$

Site abbreviation

Typus (T)

Relevés from literature (for references see Appendix 1)

Number of the relevé in the original publication

Number of the table in the original publication

Botriochloa ischaemum-Melica ciliata comm.

Avena barbata Pott ex Link

Melica ciliata L. s.1.

Galactites tomentosus Moench

Carthamus lanatus L. subsp. lanatus

Bothriochloa ischaemum (L.) Keng

Onobrychis caput-galli (L.) Lam.

Centaurea deusta Ten.

Echium vulgare L.

Globularia punctata Lapeyr

Tragopogon porrifolius L. s.l.

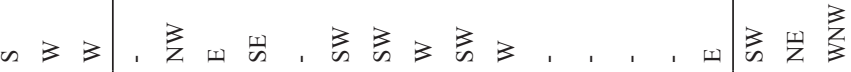

$951001001001009590 \quad 851001001001001009510010010095 \quad 100100100$ \begin{tabular}{lll|lllllllllllllll|lll}
$<$ & $<5$ & 5 & - & $<5$ & $<5$ & 10 & - & 25 & 35 & 20 & $<5$ & 5 & - & - & - & - & 50 & 30 & 40 & 40
\end{tabular} \begin{tabular}{lll|llllllllllllllll|ll}
15 & 10 & 10 & 20 & 10 & 10 & 10 & 20 & 30 & 50 & 50 & 50 & 40 & 20 & 20 & 20 & 20 & 50 & 40 & 40 & 80
\end{tabular} DG AC MV SS SS SS MV AL MVMVMVMV

\begin{tabular}{c|cccccc|ccc} 
& & & & $\mathrm{T}$ & & & \\
$\mathrm{x}$ & $\mathrm{x}$ & $\mathrm{x}$ & $\mathrm{x}$ & $\mathrm{x}$ & & $\mathrm{x}$ & $\mathrm{x}$ & $\mathrm{x}$ & $\mathrm{x}$ \\
52 & 46 & 40 & 45 & 72 & 82 & 1 & 2 & 13 \\
5 & 5 & 5 & 5 & 5 & 4 & 3 & 3 & 3 \\
\hline
\end{tabular}

Transgressive species from Rosmarinetea and other Mediterranean classes Asparagus acutifolius

Teucrium capitatum L. subsp. capitatum

Crupina vulgaris Cass.

Dorycnium hirsutum

Micromeria graeca (L.) Benth. ex Rchb. s.l.

Cistus monspeliensis L.

Plantago argentea-Carex caryophyllea comm.

Plantago argentea Chaix subsp. argentea

Koeleria lobata (M. Bieb.) Roem. \& Schult.

Bromus rubens $\mathrm{L}$.

Centaurea arrigonii Greuter

Poa bulbosa L.

Aira caryophyllea L. subsp. caryophyllea

Cerastium pumilum

Medicago minima (L.) Bartal.

Hypochaeris radicata $\mathrm{L}$.

Aphanes arvensis L.

Geranium rotundifolium L.

Gnaphalium sylvaticum L.

Coronillo minimae-Astragaletum monspessulani

Astragalus monspessulanus L. subsp. monspessulanus

Coronilla minima $\mathrm{L}$.

Linum tenuifolium $\mathrm{L}$.

Fumana procumbens (Dunal) G.et G.

Leontodon rosani (Ten.) DC.

Sesleria italica (Pamp.) Ujhelyi (diff. of subass. seslerietosum italicae)

Tragopogon samaritani-Bromus erectus comm.

Thymus pulegioides L. s.l.

Arenaria serpyllifolia L. s.1.

Silene vulgaris (Moench) Garcke s.l.

Anthyllis vulneraria L. s.l.

Teucrium montanum $\mathrm{L}$.

Tragopogon samaritani Heldr. \& Sart. ex Boiss.

Crepis staticifolia (All.) Galasso, Banfi \& Soldano 


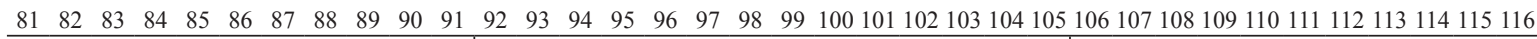

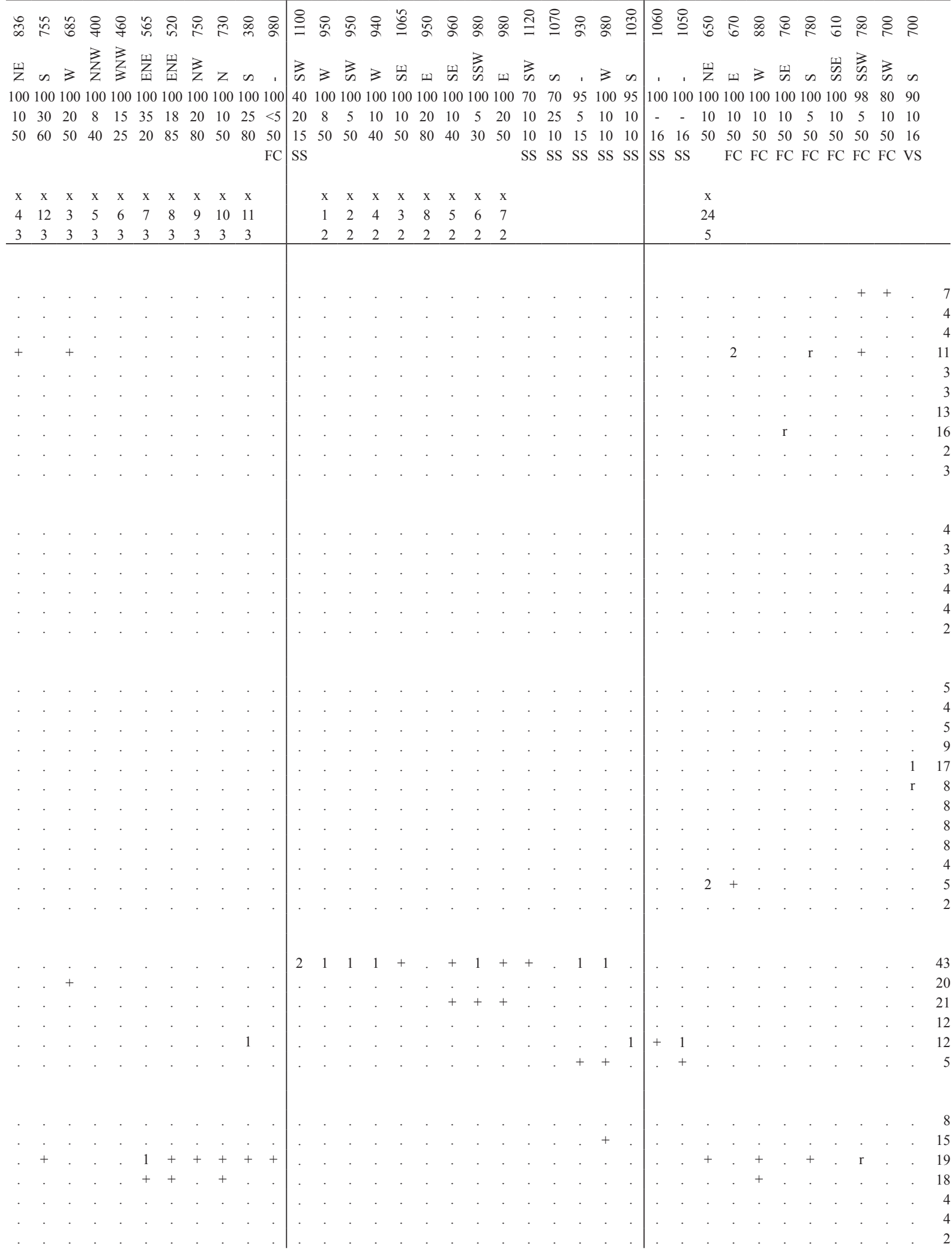


Relevé n.

$\begin{array}{lllllllllllllllllllll}1 & 2 & 3 & 4 & 5 & 6 & 7 & 8 & 9 & 10 & 11 & 12 & 13 & 14 & 15 & 16 & 17 & 18 & 19 & 20 & 21\end{array}$

Festuco trachyphyllae-Brometum erecti

Festuca stricta Host subsp. trachyphylla (Hack.) Patzke ex Pils

Sedum rupestre L. subsp. rupestre

Aira elegantissima Schur

transgressive species from Tuberarietea guttatae class

Cerastium brachypetalum Desp. ex Pers. s.1.

Linum trigynum L.

Briza maxima $\mathrm{L}$.

Vulpia myuros (L.) C.C. Gmel.

Tuberaria guttata (L.) Fourr.

Centaureo bracteatae-Brometum erecti

subass. linetosum cathartici

Medicago lupulina L.

Leontodon hispidus L.

Linum catharticum L. s.1.

subass. typicum

Galium mollugo L. subsp. erectum Syme

Centaurea scabiosa L. subsp. scabiosa

other phi-relevant species

Cota tinctoria (L.) J. Gay s.1.

Pastinaca sativa 1. subsp. urens (Req.) Celak

Elytrigia repens (L.) Nevski

Senecio erucifolius L.

Inula conyzae (Griess.) DC.

Medicago sativa L. s.1.

Acinos arvensis (Lam.) Dandy

subass. ononidetosum masquillierii

Ononis masquillierii Bertol.

Plantago maritima L. s.1.

Scorzonera cana (C.A. Mey.) O. Hoffm.

other phi-relevant species

Carlina corymbosa L.

Cichorium intybus-Bromus erectus post-cultural comm.

Cichorium intybus L. subsp. intybus

Linum strictum $\mathrm{L}$.

Poa sylvicola Guss.

Cynosurus echinatus L.

Trifolium repens L. s.1.

Bromus hordeaceus L. s.1.

Calamintha nepeta (L.) Savi s.l.

Odontites vernus (Bellardi) Dumort.

Polygalo mediterraneae-Bromenion erecti

Centaurea jacea L. subsp. gaudinii (Boiss. \& Reut.) Gremli

Dorycnium herbaceum Vill.

Asperula purpurea (L.) Ehrend. subsp. purpurea

Polygala nicaeensis W.D.J. Koch subsp. mediterranea Chodat

Carlina utzka Hacq.

\section{Bromion erecti}

Lotus corniculatus L. s.1.

Dactylis glomerata L. s.1.

Plantago lanceolata L.

Leucanthemum vulgare (Vaill.) Lam. subsp. vulgare

Briza media L.

Ononis spinosa L. s.1.

Carex caryophyllea Latourr.

Daucus carota L. s.1.

Plantago media L. subsp. media

Onobrychis viciifolia Scop.

Gymnadenia conopsea (L.) R. Br.

Linum bienne Mill.

Ranunculus bulbosus L.

Anacamptis morio (L.) R.M. Bateman, Pridgeon \& M.W. Chase Anacamptis pyramidalis (L.) Rich.

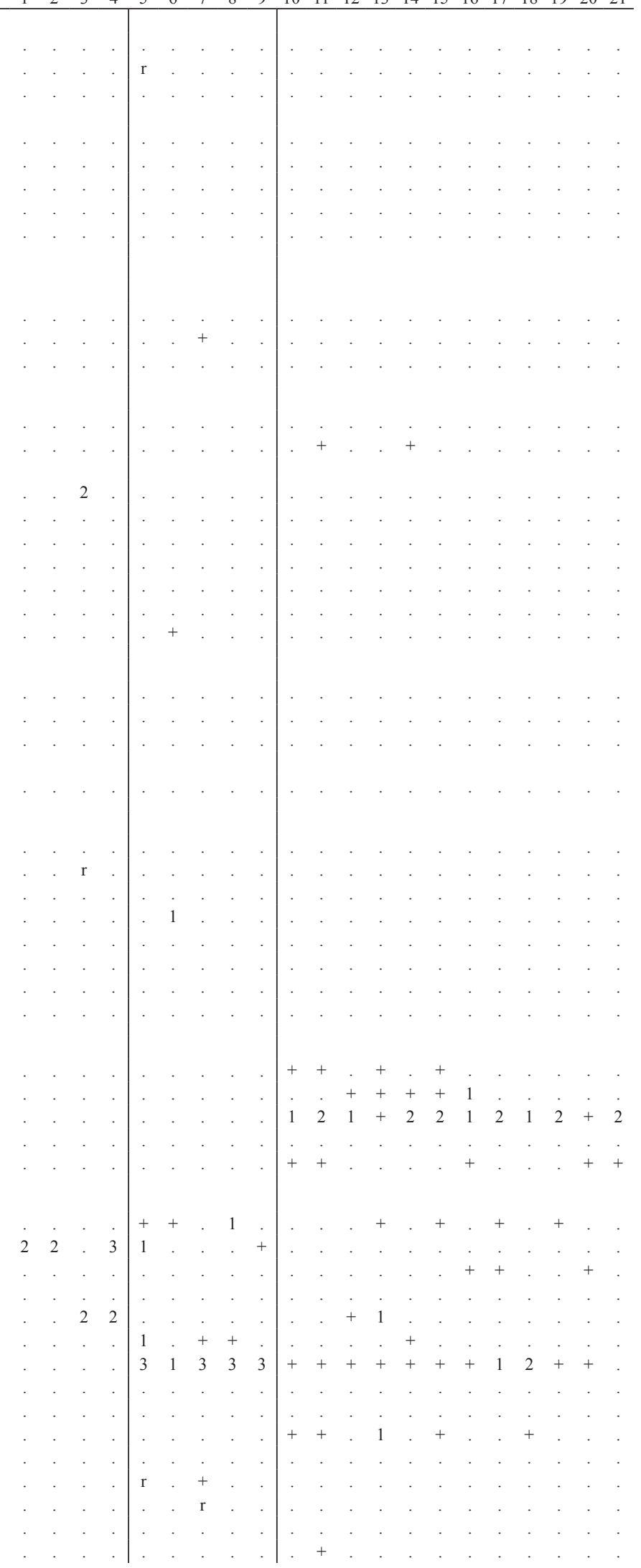




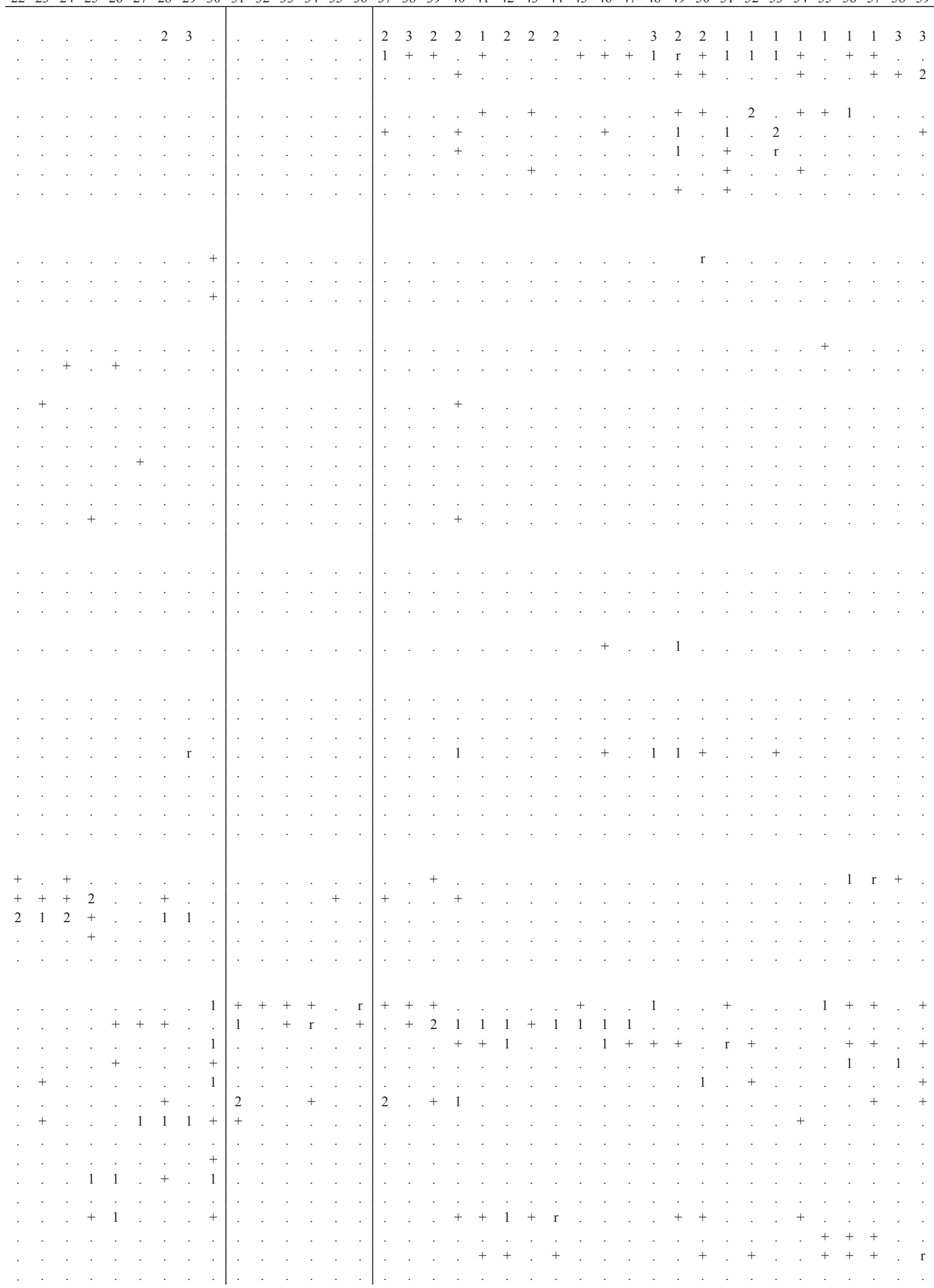


Relevé n.

$\begin{array}{lllllllllllllllllllll}60 & 61 & 62 & 63 & 64 & 65 & 66 & 67 & 68 & 69 & 70 & 71 & 72 & 73 & 74 & 75 & 76 & 77 & 78 & 79 & 80\end{array}$

Festuco trachyphyllae-Brometum erecti

Festuca stricta Host subsp. trachyphylla (Hack.) Patzke ex Pils

Sedum rupestre L. subsp. rupestre

Aira elegantissima Schur

transgressive species from Tuberarietea guttatae class

Cerastium brachypetalum Desp. ex Pers. s.1.

Linum trigynum L.

Briza maxima $\mathrm{L}$.

Vulpia myuros (L.) C.C. Gmel.

Tuberaria guttata (L.) Fourr.

Centaureo bracteatae-Brometum erecti

subass. linetosum cathartici

Medicago lupulina L.

Leontodon hispidus L.

Linum catharticum L. s.1.

subass. typicum

Galium mollugo L. subsp. erectum Syme

Centaurea scabiosa L. subsp. scabiosa

other phi-relevant species

Cota tinctoria (L.) J. Gay s.1.

Pastinaca sativa 1. subsp. urens (Req.) Celak

Elytrigia repens (L.) Nevski

Senecio erucifolius L.

Inula conyzae (Griess.) DC.

Medicago sativa L. s.1.

Acinos arvensis (Lam.) Dandy

subass. ononidetosum masquillierii

Ononis masquillierii Bertol.

Plantago maritima L. s.1.

Scorzonera cana (C.A. Mey.) O. Hoffm.

other phi-relevant species

Carlina corymbosa L.

Cichorium intybus-Bromus erectus post-cultural comm.

Cichorium intybus L. subsp. intybus

Linum strictum $\mathrm{L}$.

Poa sylvicola Guss.

Cynosurus echinatus L.

Trifolium repens L. s.1.

Bromus hordeaceus L. s.1.

Calamintha nepeta (L.) Savi s.1.

Odontites vernus (Bellardi) Dumort.

\section{Polygalo mediterraneae-Bromenion erecti}

Centaurea jacea L. subsp. gaudinii (Boiss. \& Reut.) Gremli

Dorycnium herbaceum Vill.

Asperula purpurea (L.) Ehrend. subsp. purpurea

Polygala nicaeensis W.D.J. Koch subsp. mediterranea Chodat

Carlina utzka Hacq.

\section{Bromion erecti}

Lotus corniculatus L. s.1.

Dactylis glomerata L. s.1.

Plantago lanceolata L.

Leucanthemum vulgare (Vaill.) Lam. subsp. vulgare

Briza media L.

Ononis spinosa L. s.1.

Carex caryophyllea Latourr.

Daucus carota L. s.1.

Plantago media L. subsp. media

Onobrychis viciifolia Scop.

Gymnadenia conopsea (L.) R. Br.

Linum bienne Mill.

Ranunculus bulbosus L.

Anacamptis morio (L.) R.M. Bateman, Pridgeon \& M.W. Chase Anacamptis pyramidalis (L.) Rich.

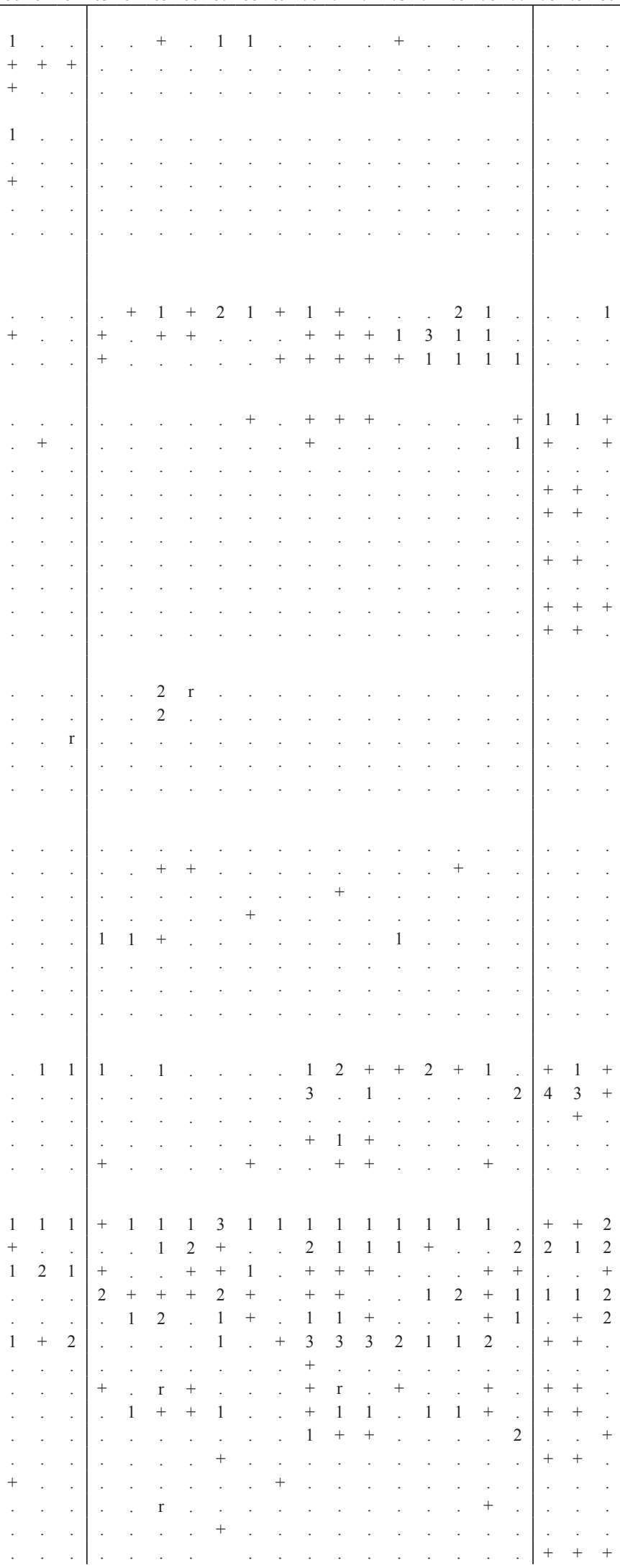




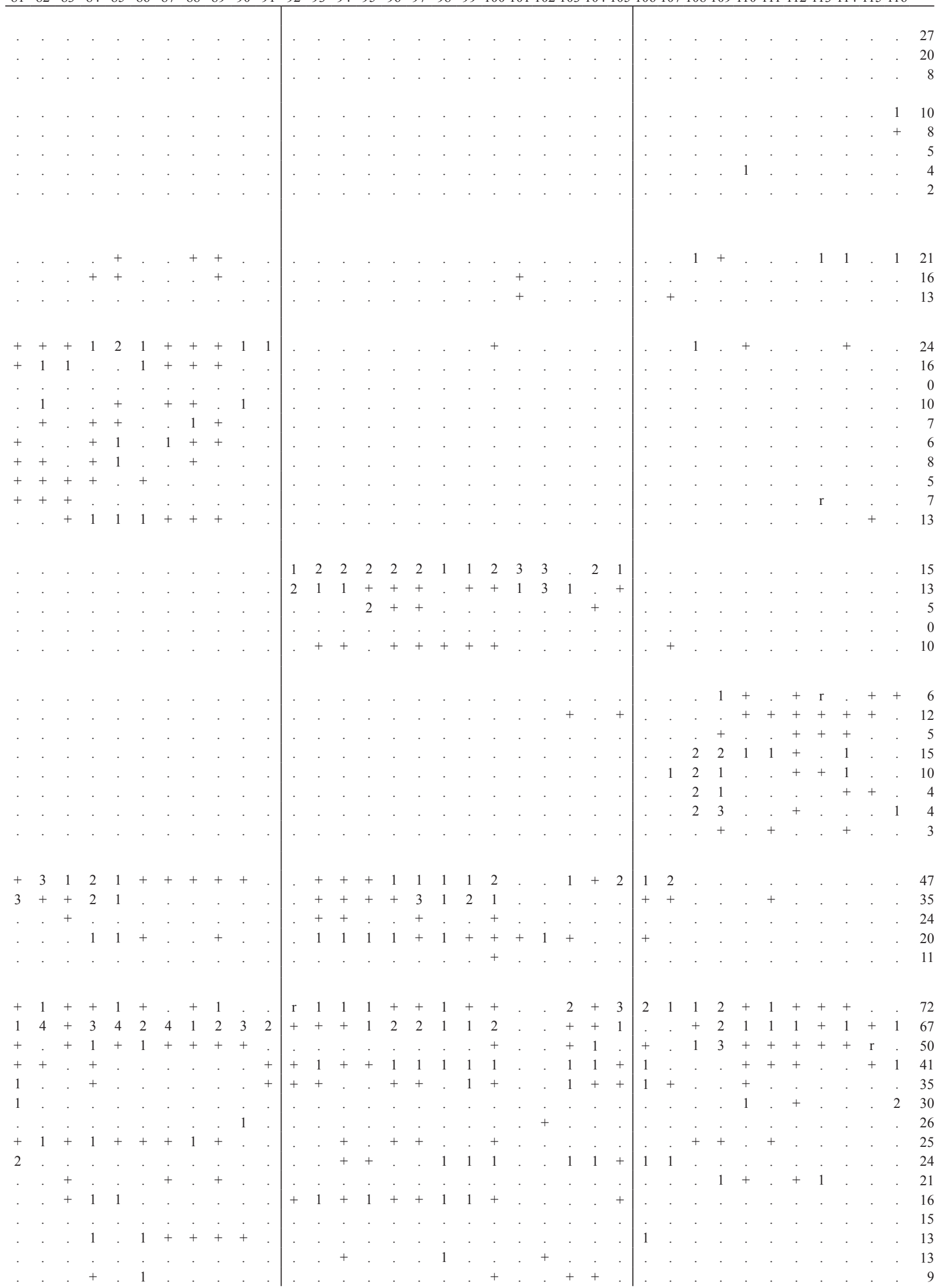


Relevé n.

\begin{tabular}{lllllllllllllllllllll}
1 & 2 & 3 & 4 & 5 & 6 & 7 & 8 & 9 & 10 & 11 & 12 & 13 & 14 & 15 & 16 & 17 & 18 & 19 & 20 & 21 \\
\hline
\end{tabular}

Knautia arvensis (L.) Coult.

Carlina acaulis L. subsp. caulescens (Lam.) Schübl. \& G. Martens

Brometalia erecti and Festuco-Brometea

Bromus erectus Huds. subsp. erectus

Sanguisorba minor Scop. s.1.

Brachypodium rupestre (Host) Roem. \& Schult.

Thymus longicaulis C. Presl subsp. longicaulis

Carex flacca Schreb. s.1.

Festuca inops De Not.

Scabiosa columbaria L. s.1.

Teucrium chamaedrys L. subsp. chamaedrys

Hippocrepis comosa L. subsp. comosa

Achillea collina s.1.

Galium lucidum All. subsp. lucidum

Hieracium pilosella $\mathrm{L}$.

Helianthemum nummularium (L.) Mill. s.1.

Galium verum L. subsp. verum

Prunella laciniata (L.) L.

Trifolium campestre Schreb.

Trifolium ochroleucum Huds.

Linum viscosum $\mathrm{L}$.

Petrorhagia prolifera (L.) P.W. Ball \& Heywood

Carlina vulgaris L. s.1.

Muscari comosum (L.) Mill.

Eryngium campestre L.

Eryngium amethystinum $\mathrm{L}$.

Allium sphaerocephalon $\mathrm{L}$.

Dianthus sylvestris Wulfen

Arabis hirsuta (L.) Scop.

Reichardia picroides

Potentilla hirta L.

Saxifraga bulbifera L.

Centaurea ambigua Guss.

Cerastium arvense L. subsp. suffruticosum (L.) Ces.

Odontites luteus (L.) Clairv.

Mentha longifolia (L.) Huds.

Petrorhagia saxifraga (L.) Link subsp. saxifraga

Arabis collina Ten. subsp. collina

Erysimum pseudorhaeticum Polatschek

Helianthemum apenninum (L.) Miller

Micropus erectus L.

Muscari neglectum Ten.

Silene italica (L.) Pers. subsp. italica

Euphrasia stricta D. Wolff ex J.F. Lehm.

Euphorbia cyparissias L.

Convolvulus cantabrica

Cyanus triumfetti (All.) Dostál ex Á. \& D. Löve

Ononis natrix L.

Thesium divaricatum Jan

Filipendula vulgaris Moench

Aegilops geniculata Roth

Artemisia alba Turra

Helianthemum canum (L.) Baumng.

Leontodon cichoriaceus (Ten.) Sanguin.

Ononis pusilla L.

Stachys recta L. s.1.

Arabis sagittata (Bertol.) DC.

Campanula glomerata L.

Koeleria macrantha (Ledeb-) Sprengel

Lathyrus sphaericus Retz.

Molinio-Arrhenatheretea

Trifolium pratense L. subsp. pratense

Anthoxanthum odoratum L. s.1.

Cynosurus cristatus L.

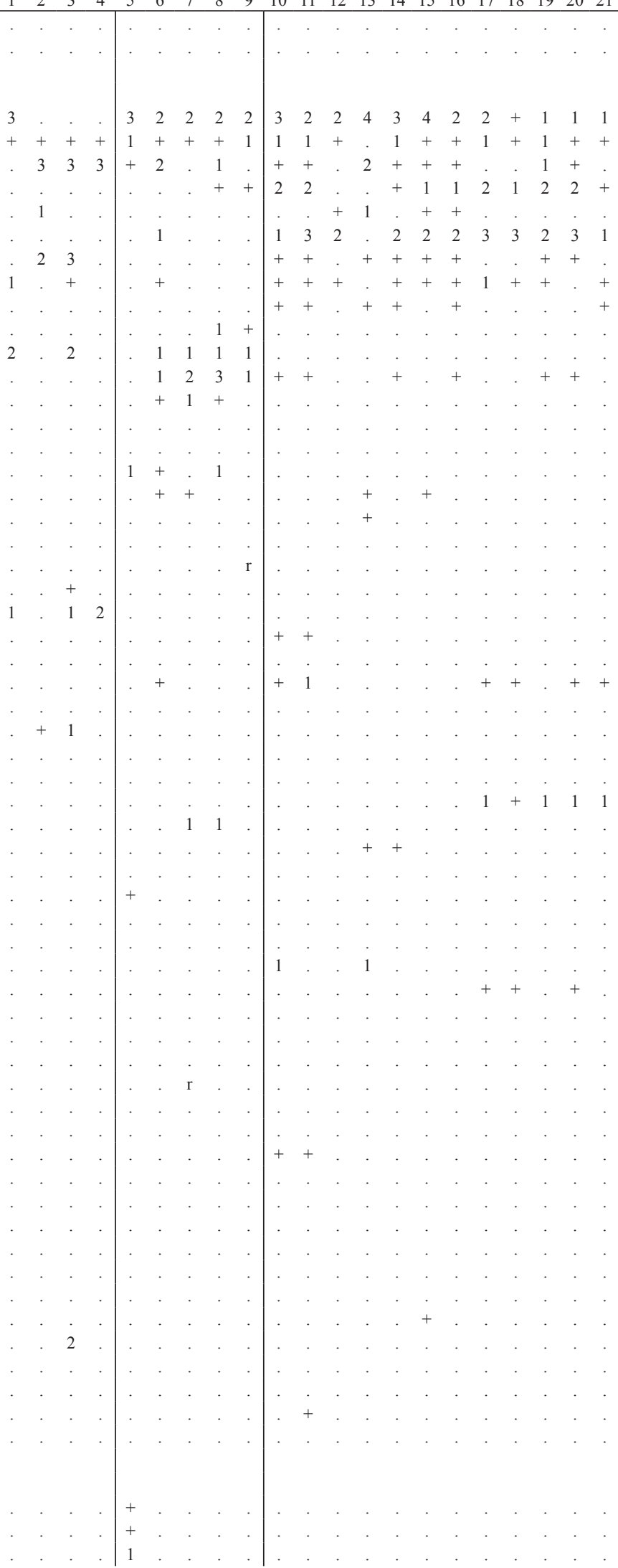




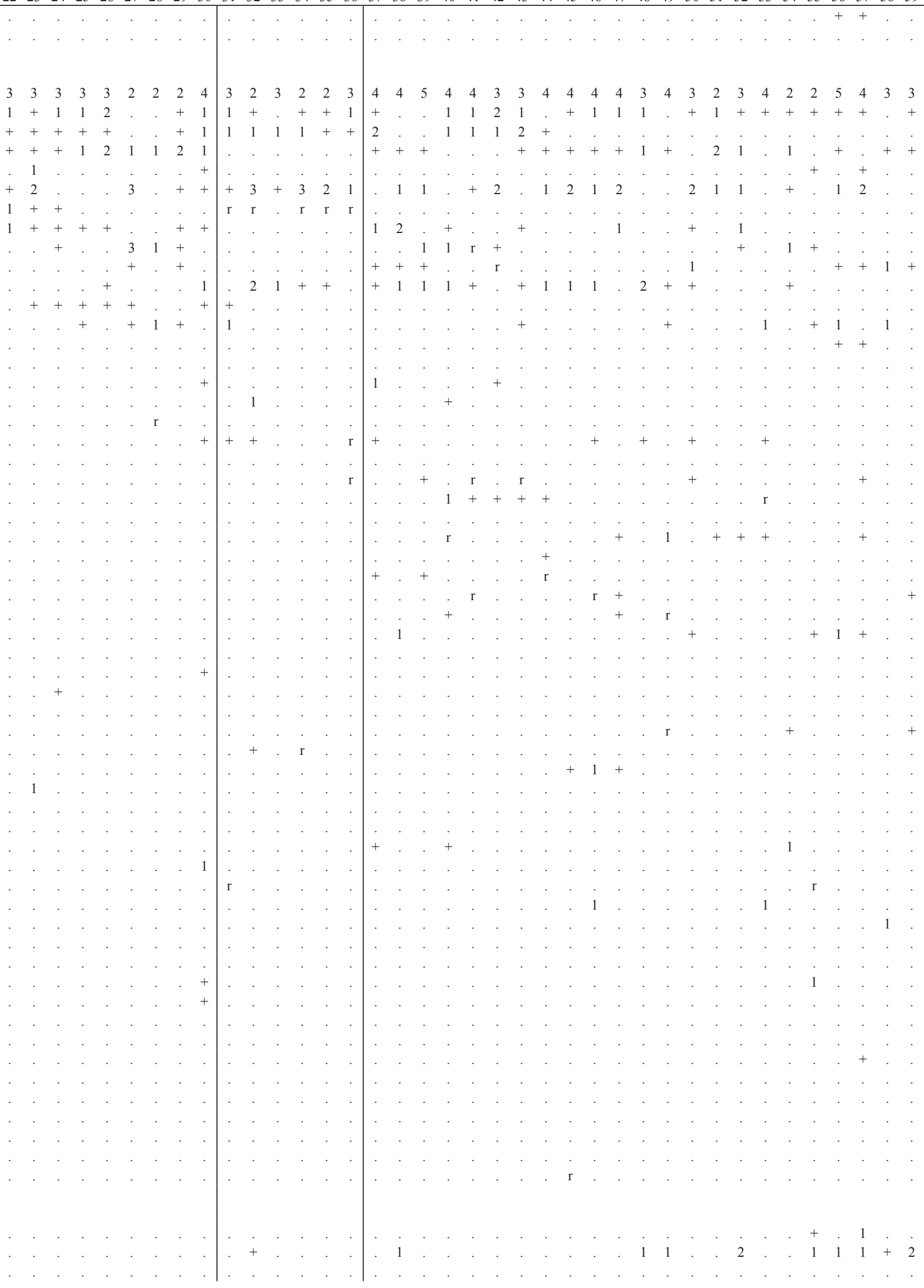


Relevé $\mathrm{n}$.

Knautia arvensis (L.) Coult.

Carlina acaulis L. subsp. caulescens (Lam.) Schübl. \& G. Martens

Brometalia erecti and Festuco-Brometea

Bromus erectus Huds. subsp. erectus

Sanguisorba minor Scop. s.1.

Brachypodium rupestre (Host) Roem. \& Schult.

Thymus longicaulis C. Presl subsp. longicaulis

Carex flacca Schreb. s.1.

Festuca inops De Not.

Scabiosa columbaria L. s.1.

Teucrium chamaedrys L. subsp. chamaedrys

Hippocrepis comosa L. subsp. comosa

Achillea collina s.1.

Galium lucidum All. subsp. lucidum

Hieracium pilosella $\mathrm{L}$.

Helianthemum nummularium (L.) Mill. s.1.

Galium verum L. subsp. verum

Prunella laciniata (L.) L.

Trifolium campestre Schreb.

Trifolium ochroleucum Huds.

Linum viscosum $\mathrm{L}$.

Petrorhagia prolifera (L.) P.W. Ball \& Heywood

Carlina vulgaris L. s.1.

Muscari comosum (L.) Mill.

Eryngium campestre L.

Eryngium amethystinum $\mathrm{L}$.

Allium sphaerocephalon L.

Dianthus sylvestris Wulfen

Arabis hirsuta (L.) Scop.

Reichardia picroides

Potentilla hirta L.

Saxifraga bulbifera L.

Centaurea ambigua Guss.

Cerastium arvense L. subsp. suffruticosum (L.) Ces.

Odontites luteus (L.) Clairv.

Mentha longifolia (L.) Huds.

Petrorhagia saxifraga (L.) Link subsp. saxifraga

Arabis collina Ten. subsp. collina

Erysimum pseudorhaeticum Polatschek

Helianthemum apenninum (L.) Miller

Micropus erectus L.

Muscari neglectum Ten.

Silene italica (L.) Pers. subsp. italica

Euphrasia stricta D. Wolff ex J.F. Lehm.

Euphorbia cyparissias L.

Convolvulus cantabrica

Cyanus triumfetti (All.) Dostál ex Á. \& D. Löve

Ononis natrix L.

Thesium divaricatum Jan.

Filipendula vulgaris Moench

Aegilops geniculata Roth

Artemisia alba Turra

Helianthemum canum (L.) Baumng.

Leontodon cichoriaceus (Ten.) Sanguin.

Ononis pusilla L.

Stachys recta L. s.1.

Arabis sagittata (Bertol.) DC.

Campanula glomerata $\mathrm{L}$.

Koeleria macrantha (Ledeb-) Sprengel

Lathyrus sphaericus Retz.

Molinio-Arrhenatheretea

Trifolium pratense L. subsp. pratense

Anthoxanthum odoratum L. s.1.

Cynosurus cristatus L. \begin{tabular}{lllllllllllllllllllll}
60 & 61 & 62 & 63 & 64 & 65 & 66 & 67 & 68 & 69 & 70 & 71 & 72 & 73 & 74 & 75 & 76 & 77 & 78 & 79 & 80 \\
\hline
\end{tabular}

\begin{tabular}{lll|lllllllllllllll|lll}
4 & 4 & 3 & 4 & 3 & 3 & 4 & 2 & 3 & 3 & 1 & 1 & 1 & 3 & 4 & 3 & 3 & 4 & 4 & 3 & 5
\end{tabular}

$1++2+\mathrm{r}+1+.+++1+1+++$

$\begin{array}{llllllllllllllllllll}1 . & 2 & 1 & + & + & 3 & 1 & 1 & 4 & 3 & 2 & 4 & 1 & 3 & 4 & 2\end{array}$

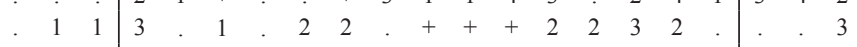

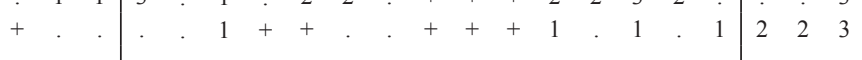

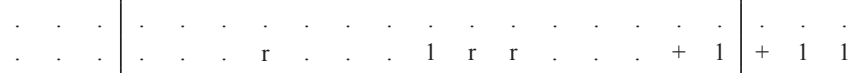

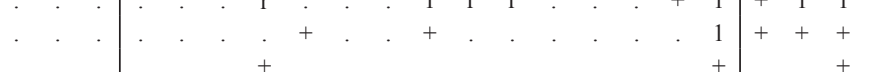

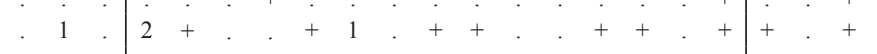

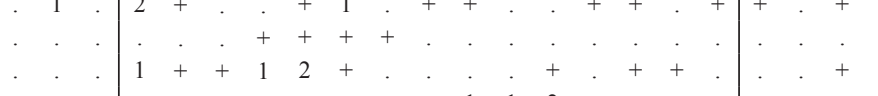

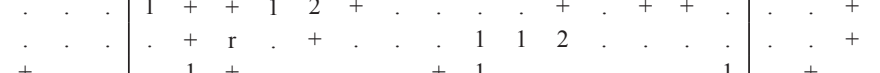

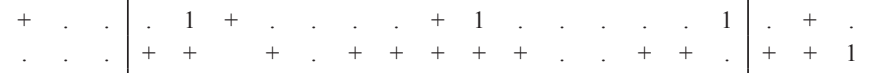

$\cdot \cdot \cdot \cdot \begin{array}{llllllllllllllllllll}\cdot & \cdot & 2 & 1 & 1 & \cdot & \cdot & \cdot & + & \cdot & \cdot & \cdot & \cdot & \cdot & \cdot & \cdot & + & \cdot & +\end{array}$

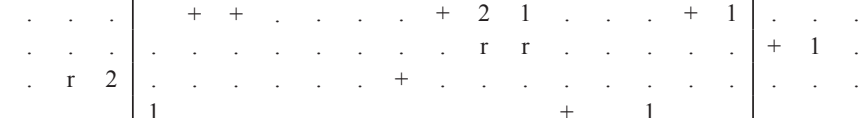

$\begin{array}{llllllllllllllllllllllllllllll}\cdot & \cdot & \cdot & 1 & \cdot & \cdot & \cdot & \cdot & \cdot & \cdot & \cdot & \cdot & \cdot & + & \cdot & 1 & \cdot & \cdot & \cdot & \cdot & \cdot \\ \cdot & \cdot & \cdot & \cdot & \cdot & \cdot & \cdot & \cdot & \cdot & \cdot & \cdot & \cdot & \cdot & \cdot & \cdot & \cdot & \cdot & \cdot & \cdot & \cdot & \cdot \\ \cdot & \cdot & \cdot & \cdot & \cdot & \cdot & \cdot & \cdot & \cdot & \cdot & \cdot & \cdot & \cdot & \cdot & \cdot & \cdot & \cdot & \cdot & \cdot & \cdot & \cdot & \cdot & \cdot\end{array}$

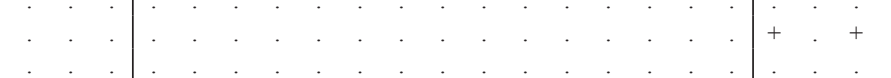

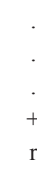

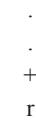




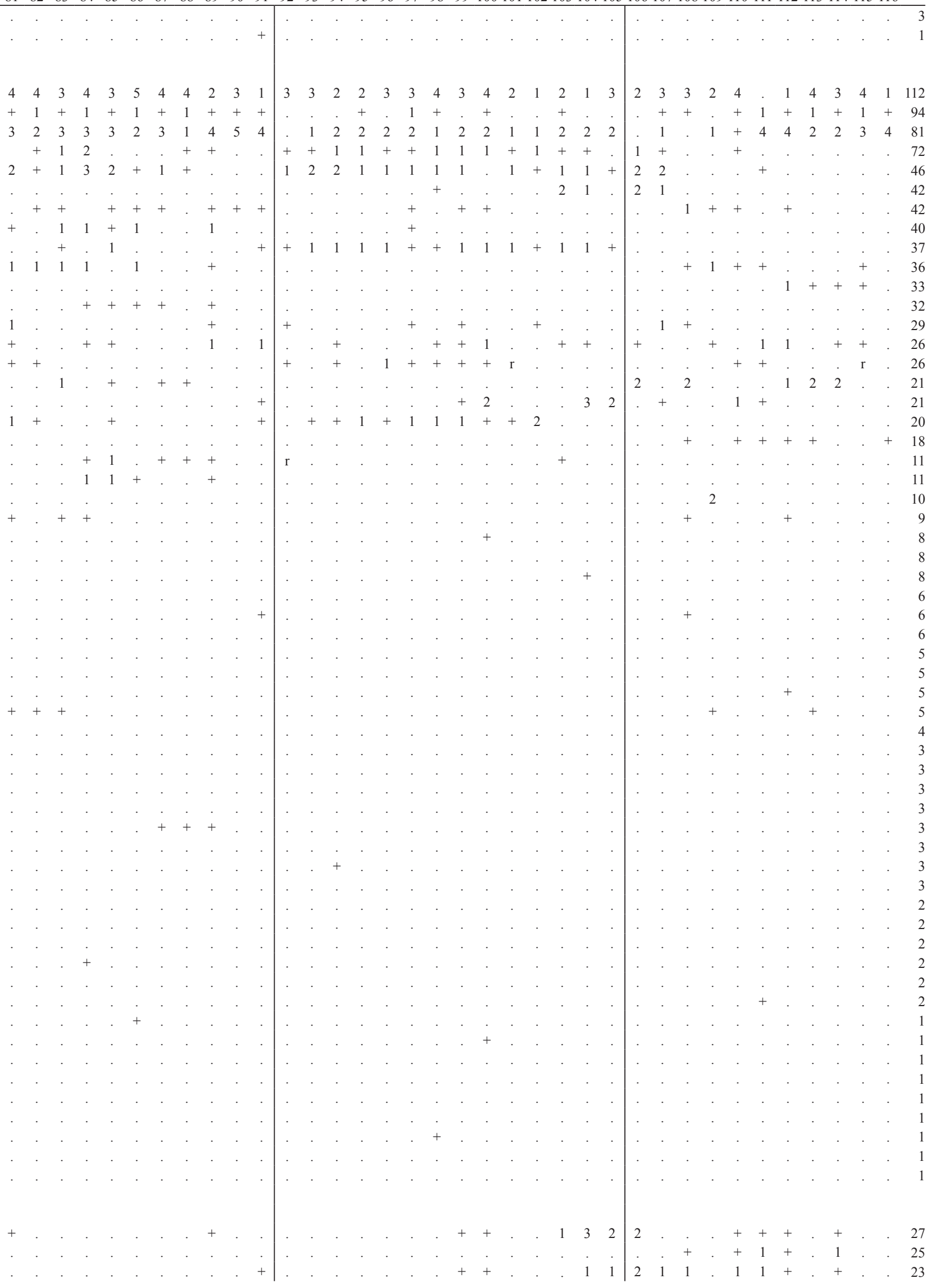


Relevé n.

\begin{tabular}{lllllllllllllllllllll}
1 & 2 & 3 & 4 & 5 & 6 & 7 & 8 & 9 & 10 & 11 & 12 & 13 & 14 & 15 & 16 & 17 & 18 & 19 & 20 & 21 \\
\hline
\end{tabular}

Schedonorus arundinaceus (Schreb.) Dumort. s.l.

Phleum pratense $\mathrm{L}$.

Lathyrus pratensis L. subsp. pratensis

Lolium perenne $\mathrm{L}$.

Rhinanthus minor $\mathrm{L}$.

Poa pratensis L.

Trisetaria flavescens (L.) Baumg. subsp. flavescens

Holcus lanatus $\mathrm{L}$.

Prunella vulgaris L. subsp. vulgaris

Bellis perennis $\mathrm{L}$.

Cerastium holosteoides Fr.

Rumex acetosa L. subsp. acetosa

Taraxacum officinale (group)

Arrhenatherum elatius (L.) P. Beauv. ex J. \& C. Presl s.1.

\section{Other species}

Hypericum perforatum $\mathrm{L}$.

Sedum sexangulare $\mathrm{L}$.

Acinos alpinus (L.) Moench s.l.

Helichrysum italicum (Roth) G. Don subsp. italicum

Genista tinctoria L.

Blackstonia perfoliata (L.) Huds. s.1.

Convolvulus arvensis $\mathrm{L}$.

Centaurium erythraea Rafn s.1.

Cuscuta epithymum (L.) L. subsp. epithymum

Agrimonia eupatoria L. s.l.

Hieracium piloselloides Vill.

Tussilago farfara $\mathrm{L}$.

Bupleurum baldense Turra

Polygala flavescens DC.

Campanula rapunculus $\mathrm{L}$.

Trifolium medium L. subsp. medium

Clinopodium vulgare L. s.l.

Dianthus carthusianorum L.

Juniperus communis L.

Cirsium tenoreanum Petr.

Lathyrus sylvestris L. subsp. sylvestris

Trifolium angustifolium L. subsp. angustifolium

Cytisus scoparius (L.) Link subsp. scoparius

Stachys germanica L. s.1.

Agrostis stolonifera $\mathrm{L}$.

Rosa canina L.

Crepis leontodontoides All.

Ranunculus nemorosus DC.

Rubus canescens DC.

Luzula campestris (L.) DC.

Quercus cerris L.

Sherardia arvensis $\mathrm{L}$.

Hypochaeris achyrophorus $\mathrm{L}$.

Rumex acetosella L. s.l.

Ornithogalum umbellatum L.

Bunium bulbocastanum L.

Cruciata laevipes Opiz

Inula salicina $\mathrm{L}$.

Vicia sativa L. subsp. nigra (L.) Ehrh.

Picris hieracioides L. s.l.

Poa compressa L.

Xeranthemum cylindraceum $\mathrm{Sm}$.

Centaurea nigrescens Willd. s.l.

Geranium columbinum L.

Carduus nutans L. s.l.

Ajuga iva (L.) Schreb. subsp. iva

Melilotus neapolitanus Ten.

Trifolium stellatum $\mathrm{L}$.

Danthonia alpina Vest

Stachys officinalis (L.) Trevis.

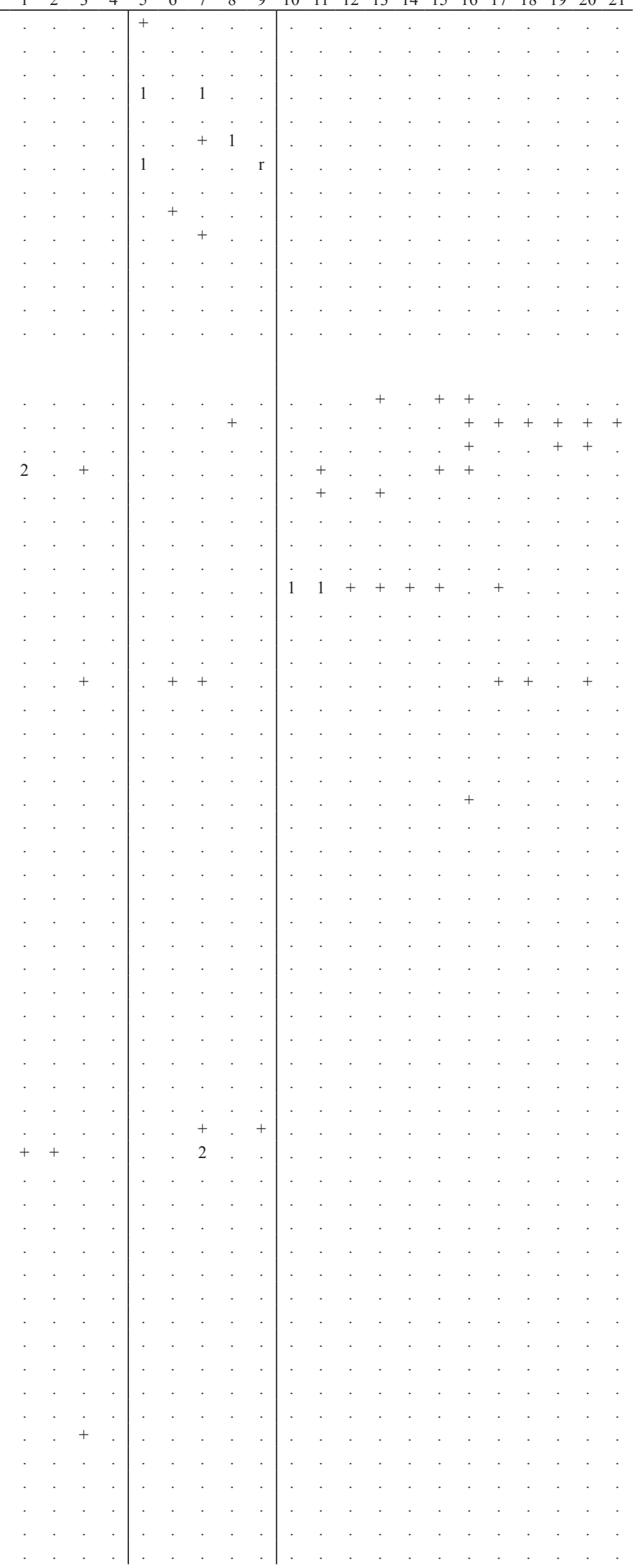




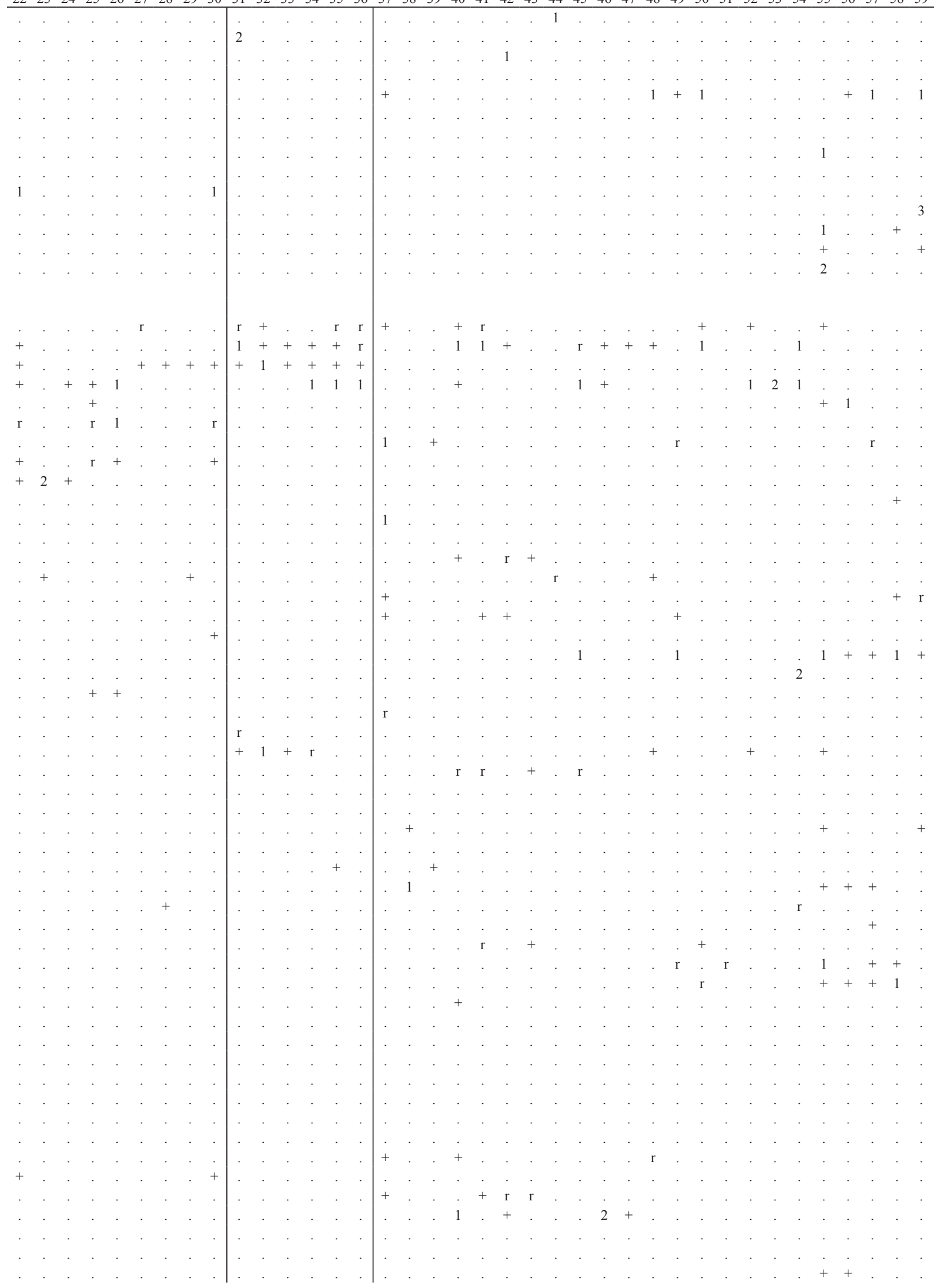


Relevé n.

$\begin{array}{lllllllllllllllllllll}60 & 61 & 62 & 63 & 64 & 65 & 66 & 67 & 68 & 69 & 70 & 71 & 72 & 73 & 74 & 75 & 76 & 77 & 78 & 79 & 80\end{array}$

Schedonorus arundinaceus (Schreb.) Dumort. s.1.

Phleum pratense $\mathrm{L}$.

Lathyrus pratensis L. subsp. pratensis

Lolium perenne $\mathrm{L}$.

Rhinanthus minor L.

Poa pratensis L.

Trisetaria flavescens (L.) Baumg. subsp. flavescens

Holcus lanatus L.

Prunella vulgaris L. subsp. vulgaris

Bellis perennis L.

Cerastium holosteoides Fr.

Rumex acetosa L. subsp. acetosa

Taraxacum officinale (group)

Arrhenatherum elatius (L.) P. Beauv. ex J. \& C. Presl s.1.

\section{Other species}

Hypericum perforatum $\mathrm{L}$.

Sedum sexangulare $\mathrm{L}$.

Acinos alpinus (L.) Moench s.1.

Helichrysum italicum (Roth) G. Don subsp. italicum

Genista tinctoria L.

Blackstonia perfoliata (L.) Huds. s.l.

Convolvulus arvensis L.

Centaurium erythraea Rafn s.1.

Cuscuta epithymum (L.) L. subsp. epithymum

Agrimonia eupatoria L. s.1.

Hieracium piloselloides Vill.

Tussilago farfara $\mathrm{L}$.

Bupleurum baldense Turra

Polygala flavescens DC.

Campanula rapunculus $\mathrm{L}$.

Trifolium medium L. subsp. medium

Clinopodium vulgare L. s.1.

Dianthus carthusianorum L.

Juniperus communis L.

Cirsium tenoreanum Petr.

Lathyrus sylvestris L. subsp. sylvestris

Trifolium angustifolium L. subsp. angustifolium

Cytisus scoparius (L.) Link subsp. scoparius

Stachys germanica L. s.1.

Agrostis stolonifera L.

Rosa canina L.

Crepis leontodontoides All.

Ranunculus nemorosus DC.

Rubus canescens DC.

Luzula campestris (L.) DC.

Quercus cerris L.

Sherardia arvensis L.

Hypochaeris achyrophorus L.

Rumex acetosella L. s.1.

Ornithogalum umbellatum L.

Bunium bulbocastanum L.

Cruciata laevipes Opiz

Inula salicina L.

Vicia sativa L. subsp. nigra (L.) Ehrh.

Picris hieracioides L. s.1.

Poa compressa L.

Xeranthemum cylindraceum $\mathrm{Sm}$.

Centaurea nigrescens Willd. s.1.

Geranium columbinum L.

Carduus nutans L. s.l.

Ajuga iva (L.) Schreb. subsp. iva

Melilotus neapolitanus Ten.

Trifolium stellatum L.

Danthonia alpina Vest

Stachys officinalis (L.) Trevis.

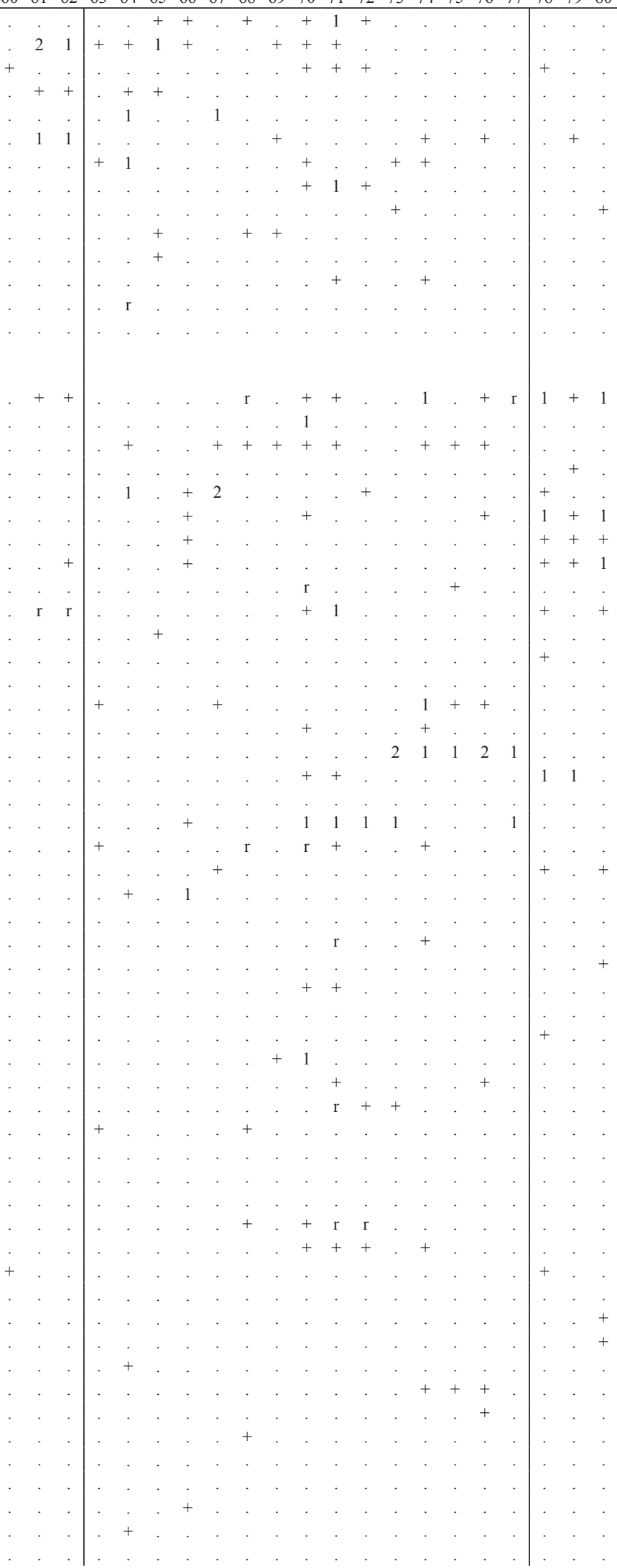




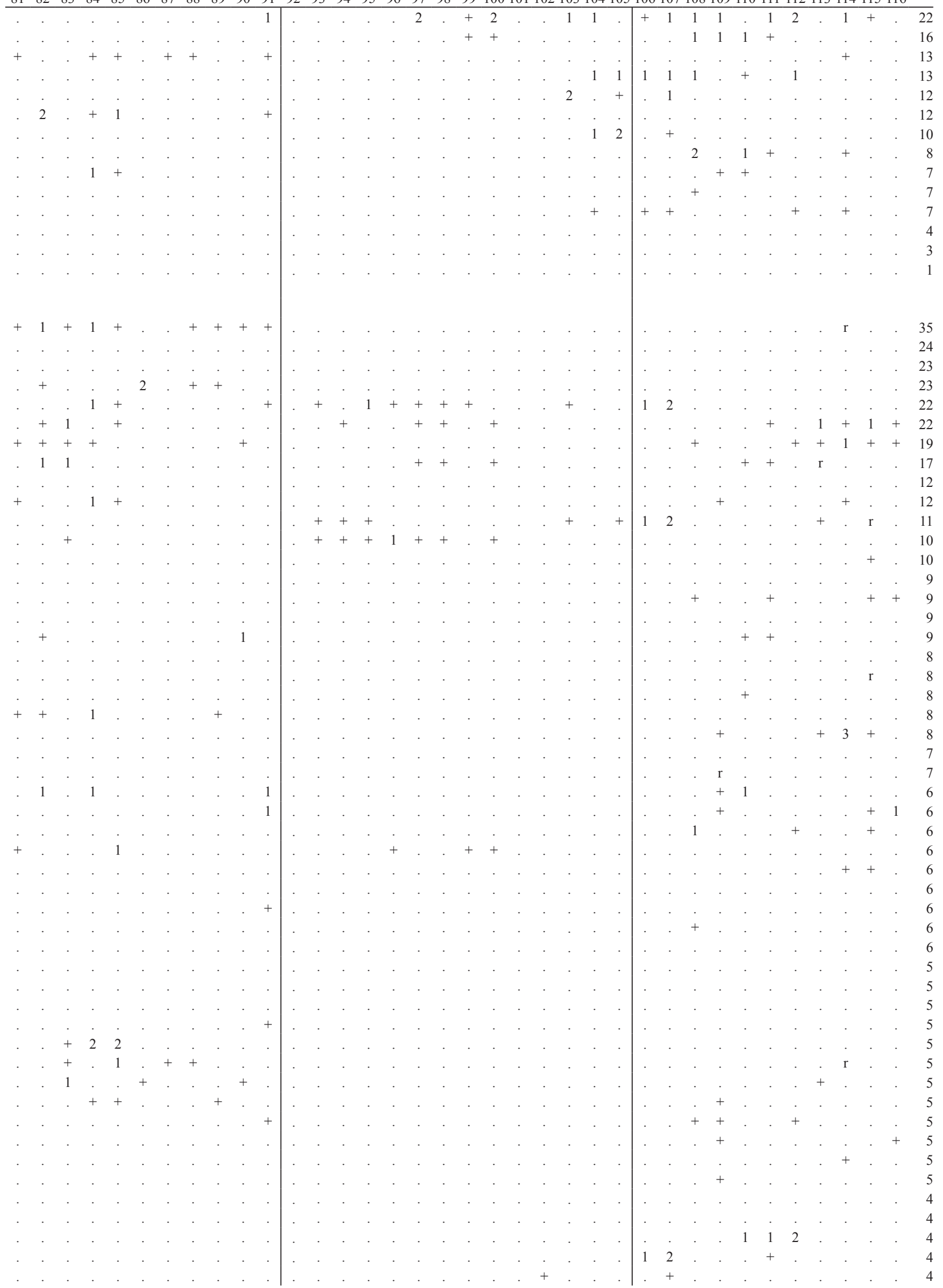


Relevé n. $\begin{array}{lllllllllllllllllllll}1 & 2 & 3 & 4 & 5 & 6 & 7 & 8 & 9 & 10 & 11 & 12 & 13 & 14 & 15 & 16 & 17 & 18 & 19 & 20 & 21\end{array}$

Potentilla reptans $\mathrm{L}$.

Festuca rubra L. subsp. commutata (Gaudin) Markgr.-Dann.

Prunus spinosa L. subsp. spinosa

Rubus ulmifolius Schott

Vicia cracca $\mathrm{L}$.

Clematis vitalba $\mathrm{L}$.

Veronica chamaedrys L. subsp. chamaedrys

Orobanche rapum-genistae Thuill. subsp. rapum-genistae

Gladiolus italicus Miller

Solidago virgaurea $\mathrm{L}$.

Sonchus asper (L.) Hill

Ophrys fusca Link

Ophrys sphecodes Miller

Festuca microphylla (St.-Yves ex Coste) Patzke

Agrostis capillaris $\mathrm{L}$.

Pteridium aquilinum (L.) Kuhn subsp. aquilinum

Lilium bulbiferum L. subsp. croceum (Chaix) Jan

Melilotus indicus (L.) All.

Oenanthe pimpinelloides $\mathrm{L}$.

Potentilla recta L. subsp. recta

Pyrus communis L.

Urospermum dalechampii (L.) F.W. Schmidt

$\underline{\text { Sporadic species }}$

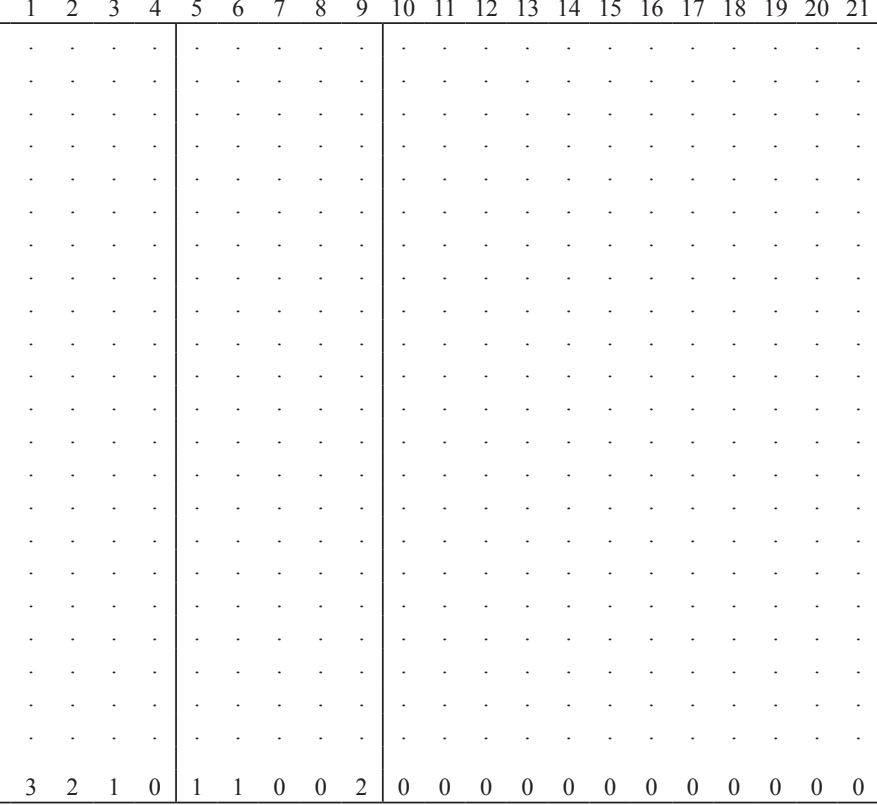

Relevé n.

$\begin{array}{lllllllllllllllllllll}60 & 61 & 62 & 63 & 64 & 65 & 66 & 67 & 68 & 69 & 70 & 71 & 72 & 73 & 74 & 75 & 76 & 77 & 78 & 79 & 80\end{array}$

Potentilla reptans L.

Festuca rubra L. subsp. commutata (Gaudin) Markgr.-Dann.

Prunus spinosa L. subsp. spinosa

Rubus ulmifolius Schott

Vicia cracca $\mathrm{L}$.

Clematis vitalba $\mathrm{L}$.

Veronica chamaedrys L. subsp. chamaedrys

Orobanche rapum-genistae Thuill. subsp. rapum-genistae

Gladiolus italicus Miller

Solidago virgaurea $\mathrm{L}$.

Sonchus asper (L.) Hill

Ophrys fusca Link

Ophrys sphecodes Miller

Festuca microphylla (St.-Yves ex Coste) Patzke

Agrostis capillaris L.

Pteridium aquilinum (L.) Kuhn subsp. aquilinum

Lilium bulbiferum L. subsp. croceum (Chaix) Jan

Melilotus indicus (L.) All.

Oenanthe pimpinelloides $\mathrm{L}$.

Potentilla recta L. subsp. recta

Pyrus communis $\mathrm{L}$.

Urospermum dalechampii (L.) F.W. Schmidt

$\underline{\text { Sporadic species }}$

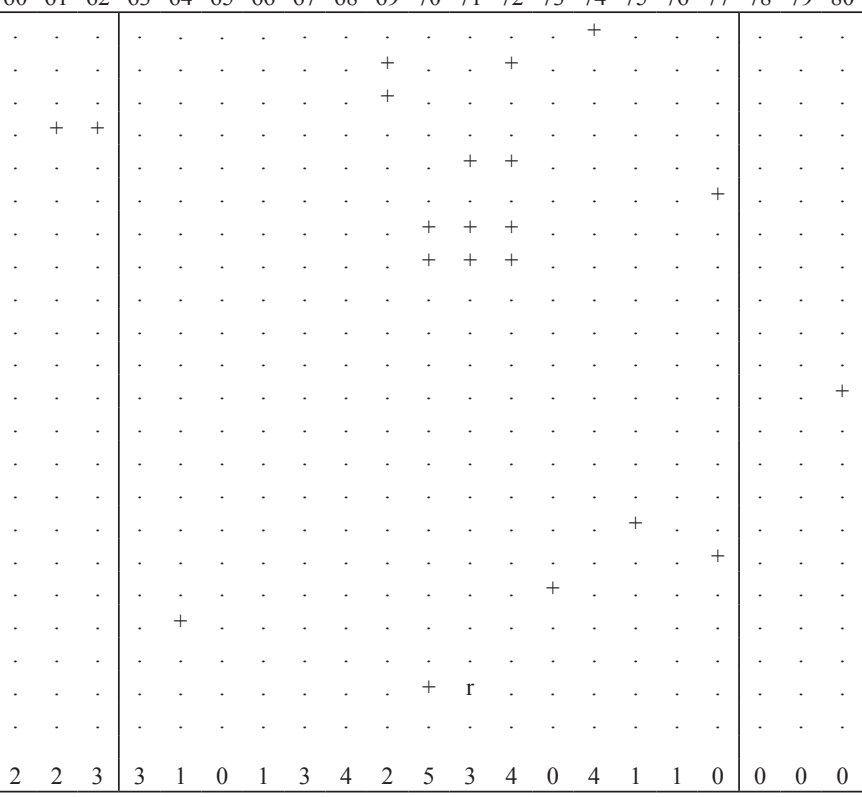

Bothriochloa ischaemum, Melica ciliata comm. (rel. 1-4)

Plantago argentea-Carex caryophyllea communities (rel. 5-9)

Coronillo minimae-Astragaletum monspessulani Biondi \& Ballelli in Biondi, Ballelli \& Principi 1985 (rel. 10-30)

Tragopogon samaritani-Bromus erectus communities (rel. 31-36)

Festuco trachyphyllae-Brometum erecti ass. nova hoc loco (rel. 37-62; typus rel. n. 49)

Centaureo bracteatae-Brometum erecti linetosum cathartici subass. nova hoc loco (rel. 63-77; typus rel. n. 76)

Centaureo bracteatae-Brometum erecti Biondi, Ballelli, Allegrezza, Guitian \& Taffetani 1986 subass. typicum (rel. 78-91; typus: rel. n. 3, Table 3 in Biondi et al. 1986)

Centaureo bracteatae-Brometum erecti ononidetosum masquillerii (Biondi, Allegrezza, Guitian \& Taffetani 1988) stat. novo (rel. 92-105; typus rel. n. 5 in Tab. 2 in Biondi et al. 1988)

Cichorium intybus-Bromus erectus post-cultural grasslands (rel. 106-116) 


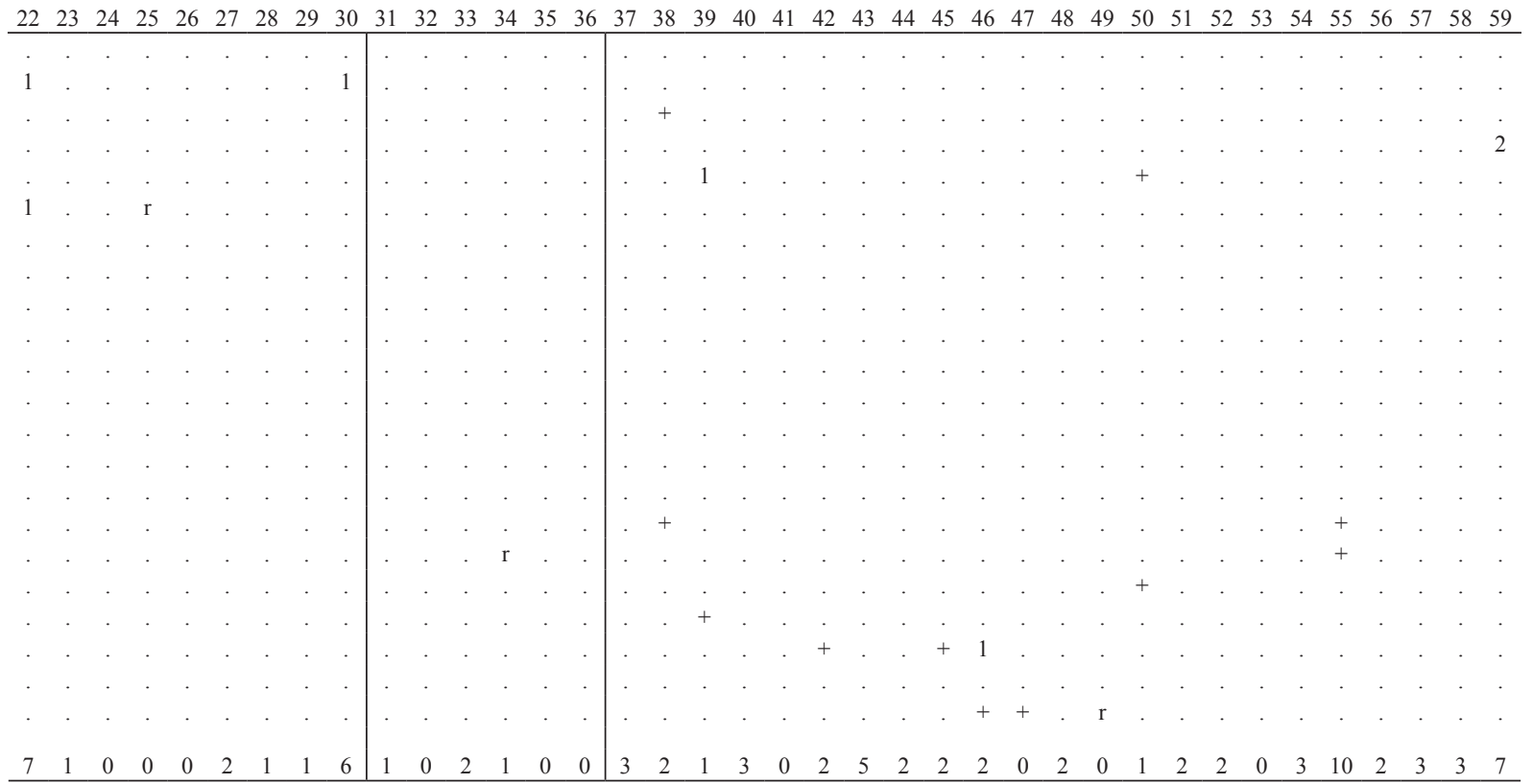

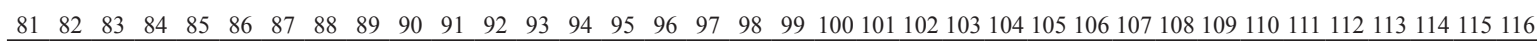

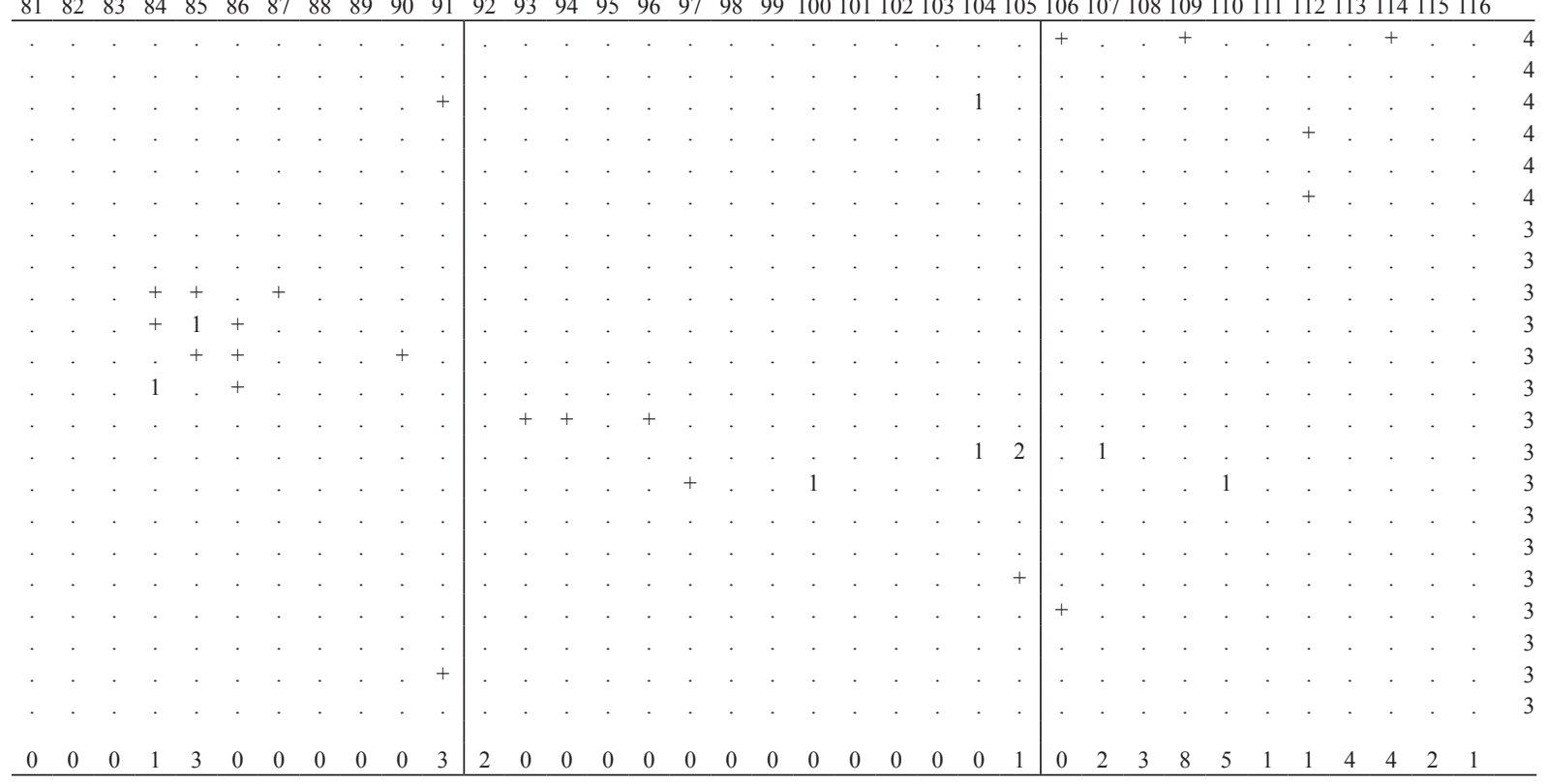


Table 2: Synoptic table of the nine detected groups with frequency (in bold) and fidelity phi-coefficient. The abbreviations of the groups are the same as in Figure 2.

Table 2: Sinoptična tabela devetih združb s prikazano frekvenco (krepko) in phi-koeficientom navezanosti. Okrajšave skupin so enake kot pri sliki 2.

$\%$ PHI \% PHI \% PHI \% PHI \% PHI \% PHI \% $\mathrm{PHI} \%$ PHI \% $\mathrm{PHI}$

BM PL CA TB FB CAL CAT CAO PC

Botriochloa ischaemum-Melica ciliata comm.

Melica ciliata L. s.1.

Galactites tomentosus Moench

Avena barbata Pott ex Link

100100

Onobrychis caput-galli (L.) Lam.

100100

10091

$\begin{array}{ll}75 & 85\end{array}$

Bothriochloa ischaemum (L.) Keng

$\begin{array}{ll}75 & 85\end{array}$

Carthamus lanatus L. subsp. lanatus

10081

Globularia punctata Lapeyr

Tragopogon porrifolius L. s.1.

Centaurea deusta Ten.

Echium vulgare L.

Transgressive species from Rosmarinetea and other Mediterranean veg. classes

Asparagus acutifolius

100100

Crupina vulgaris Cass.

Teucrium capitatum L. subsp. capitatum

Dorycnium hirsutum

Cistus monspeliensis L.

Micromeria graeca (L.) Benth. ex Rchb. s.l.

\section{Plantago argentea-Carex caryophyllea comm.}

Plantago argentea Chaix subsp. argentea

Koeleria lobata (M. Bieb.) Roem. \& Schult.

Bromus rubens L.

Aira caryophyllea L. subsp. caryophyllea

Cerastium pumilum

Centaurea arrigonii Greuter

Medicago minima (L.) Bartal.

Aphanes arvensis L.

Geranium rotundifolium $\mathrm{L}$.

Gnaphalium sylvaticum L.

Hypochaeris radicata $\mathrm{L}$.

Poa bulbosa L.

\section{Coronillo minimae-Astragaletum monspessulani}

Coronilla minima $\mathrm{L}$.

Linum tenuifolium $\mathrm{L}$.

Astragalus monspessulanus L. subsp. monspessulanus

Leontodon rosani (Ten.) DC.

Fumana procumbens (Dunal) G.et G.

Tragopogon samaritani-Bromus erectus comm.

Thymus pulegioides L. s.l.

Tragopogon samaritani Heldr. \& Sart. ex Boiss.

Teucrium montanum L.

Arenaria serpyllifolia L. s.l.

Anthyllis vulneraria L. s.l.

Silene vulgaris (Moench) Garcke s.l.

Crepis staticifolia (All.) Galasso, Banfi \& Soldano

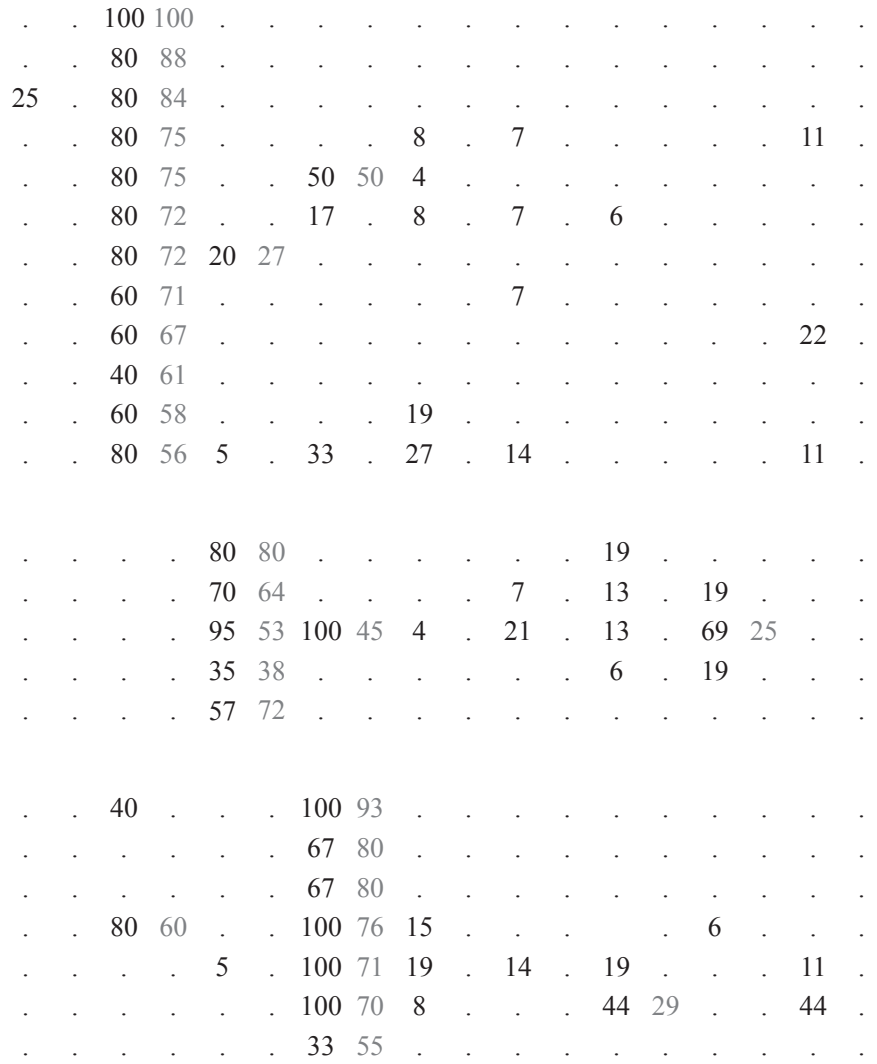


$\%$ PHI \% PHI \% PHI \% PHI \% PHI \% PHI \% PHI \% PHI \% PHI

BM PL CA $\quad$ TB $\quad$ FB CAL CAT CAO PC

Festuco trachyphyllae-Brometum erecti

Sedum rupestre L. subsp. rupestre

20 . . . . 7379

Festuca stricta subsp. trachyphylla (Hack.) Patzke ex Pils . . . . . 15 . . . . 816429

Aira elegantissima Schur

Centaureo bracteatae-Brometum erecti subass. linetosum cathartici

Leontodon hispidus L.

Linum catharticum L. s.1.

Medicago lupulina L.

$\begin{array}{ccccccccccccccccc}20 & . & . & . & . & . & 4 & . & 71 & 62 & 19 & . & 6 & . & . & . \\ . & . & 5 & . & . & . & . & . & 64 & 60 & 6 & . & 13 & . & . & . \\ . & . & 5 & . & . & . & 4 & . & 71 & 50 & 25 & . & . & . & 56 & .\end{array}$.

subass. typicum

Galium mollugo L. subsp. erectum Syme

Centaurea scabiosa L. subsp. scabiosa

Cota tinctoria (L.) J. Gay s.l.

Pastinaca sativa 1. subsp. urens (Req.) Celak

Elytrigia repens (L.) Nevski

Senecio erucifolius L.

Acinos arvensis (Lam.) Dandy

Inula conyzae (Griess.) DC.

Medicago sativa L. s.l.

subass. ononidetosum masquillierii

Ononis masquillierii Bertol.

Plantago maritima L. s.l.

Scorzonera cana (C.A. Mey.) O. Hoffm.

Carlina corymbosa L.

Cichorium intybus-Bromus erectus post-cultural comm.

Cichorium intybus L. subsp. intybus

Bromus hordeaceus L. s.l.

Calamintha nepeta (L.) Savi s.1.

Linum strictum L.

Poa sylvicola Guss.

Odontites vernus (Bellardi) Dumort.

Cynosurus echinatus L.

Trifolium repens L. s.1.

Polygalo mediterraneae-Bromenion erecti

Centaurea jacea L. subsp. gaudinii (Boiss. \& Reut.) Gremli Dorycnium herbaceum Vill.

Linum viscosum $\mathrm{L}$.

Asperula purpurea (L.) Ehrend. subsp. purpurea

Polygala nicaeensis W.D.J. Koch subsp. mediterranea Chodat

Carlina utzka Hacq.

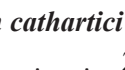

\section{Bromion erecti}

Lotus corniculatus L. s.1.

Dactylis glomerata L. s.l.

Ononis spinosa L. s.l.

Plantago lanceolata L.

Carex caryophyllea Latourr.

Briza media L.

Linum bienne Mill.

Daucus carota L. s.1.

Gymnadenia conopsea (L.) R. Br.

Plantago media L. subsp. media

\begin{tabular}{|c|c|c|c|c|c|c|c|c|c|c|c|c|c|c|c|c|}
\hline & 60 & & 20 & & 83 & & 50 & & 100 & 29 & 75 & & 88 & & 78 & \\
\hline 75 & . 40 & & 15 & & 67 & & 42 & & 57 & & 94 & 28 & 75 & & 100 & 31 \\
\hline & . 60 & & 5 & . & 33 & & 31 & & 64 & 34 & 19 & 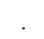 & . & & 33 & \\
\hline & . & & 20 & . & & & 58 & & 57 & . & 69 & 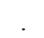 & 25 & 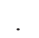 & 89 & 32 \\
\hline & . 100 & 59 & 70 & 53 & 17 & & 4 & & 7 & & 13 & 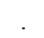 & 6 & & 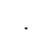 & \\
\hline & . & . & 5 & . & . & & 12 & . & 57 & . & 44 & . & 69 & 33 & 11 & \\
\hline & . 40 & . & 15 & . & . & & 35 & 28 & 7 & . & . & . & . & . & . & \\
\hline & . & . & . & . & . & & . & . & 50 & . & 69 & 45 & 25 & . & 33 & \\
\hline & . & . & . & . & ${ }^{\circ}$ & & . & . & 7 & . & 31 & . & 63 & 55 & . & \\
\hline & . & & & & & & & & 71 & 47 & 19 & . & 63 & 40 & & \\
\hline
\end{tabular}

